\title{
Cachexia - The Interplay Between the Immune System, Brain Control and Metabolism
}

\author{
Andrea Stofkova \\ Department of Normal, Pathological, and Clinical Physiology, \\ Third Faculty of Medicine, Charles University in Prague, Prague, \\ Czech Republic
}

\section{Introduction}

Systemic inflammation involves powerful immune response that interferes with homeostatic regulation of many physiological processes including those controlling appetite and nutritional balance. In advanced chronic diseases, such as chronic obstructive pulmonary disease (COPD), rheumatoid arthritis, chronic infection or sepsis, renal failure, heart failure and cancer, the immune response is frequently exaggerated insofar as it ultimately leads to a severe debilitating state known as cachexia. It is well known that this condition deteriorates the quality of life and predicts increased morbidity and mortality. According to a recent definition, cachexia is characterized as a complex metabolic syndrome associated with a loss of body weight. In this condition, inflammation, anorexia, insulin resistance and increased muscle protein breakdown are present and result in depletion of skeletal muscle with or without a loss of fat mass (Evans et al., 2008). These hallmarks considerably distinguish cachexia from other conditions that are also associated with catabolic/anabolic imbalance or body composition disorders (e.g. starvation, dehydratation, sarcopenia, malabsorption, hyperthyroidism and lipoatrophy). At present, despite the clinical relevance of cachexia and an increasing interest of scientists and clinicians in this topic, its causal mechanisms are not yet completely understood. There is a large body of evidence that inflammation is a crucial factor in the pathogenesis of cachexia. Since proinflammatory cytokines, such as tumor necrosis factor-alpha (TNF-a), interleukin (IL)-1, and IL-6, are able to modulate brain functions, dysregulate hormone levels or cause metabolic disturbances, these molecules are of paramount importance. Nonetheless, in the multidimensional nature of cachexia it is apparent that this process is a very complex one and the underlying mechanisms do not encompass only the cytokines, but rather cytokines along with many other inflammatory mediators, hormones, neurotransmitters and metabolic factors. This chapter reviews the current knowledge about the role of cytokines in the pathogenesis of anorexia, insulin resistance and muscle catabolism as the main features of cachexia in human inflammatory diseases and their experimental animal models. The presented insight into the intertwined immune, neuroendocrine and metabolic pathways contributing to cachexia may lead to a better understanding of this pathological phenomenon appearing in chronic diseases and to possible directions for future research. 


\section{Anorexia and starvation in inflammatory diseases}

Lack of appetite and weight loss in inflammatory diseases are common components of a set of nonspecific symptoms called sickness behavior that occurs under conditions of almost any infection or inflammation. The sickness behavior means disorders in motivational behavior such as hypersomnia, fatigue, temperature change (fever or hypothermia), anorexia, adipsia, cognitive changes, depressed mood, reduced aggression, exploration activity or reproductive behavior (sexual, maternal or paternal behavior). This altered behavior is an energy-conservation and -redistribution strategy of the body towards defense against noxious agents and generation of fever that exert a high energetic cost (Lorton et al., 2008). Generally, basal metabolic rate goes up about $25 \%$ by the activation of the immune system (Straub et al., 2010). Thus sickness behavior represents a valuable homeostatic mechanism for survival towards energy reserves not to be depleted by immune processes.

In this context, the advantage of appetite loss may appear to be controversial considering that food intake is a basic behavior to keep energy reserves. However, there are several mechanisms by which anorexia increases survival capacity. Its value in the energy conservation consists particularly in reduction of energy expenditure by decreasing physical activity since there is no search effort for food, and by eliminating the energy necessary for food processing (the thermic effect of food). Furthermore, decreased foraging behavior protects sick animal from predators, and reduced food consumption limits the nutriments available for the growth of microorganisms (Delahanty \& Cremeans-Smith, 2002).

Nevertheless, only the short-term anorexia or starvation may be advantageous to cope with transient inflammation attack. A lasting anorexia ultimately leads to devastating state of malnutrition followed by inevitable muscle proteocatabolism. In fact, persistent anorexia and poor nutrient status have been observed in patients with chronic inflammatory diseases and cancer (Evans et al., 2008; Laviano et al., 2008; Straub et al., 2010).

There is strong evidence approving a failure of homeostatic mechanisms that control energy balance in conditions of long-term immune activation. The hypothalamus is the main regulatory center of the energy homeostasis. Hypothalamic areas contain neurons expressing orexigenic and anorexigenic neuropeptides that are modulated by peripheral signals. The major role is played by gastrointestinal signal of hunger ghrelin, and adiposity and satiety signal leptin. Ghrelin is released from stomach in response to starvation and activates orexigenic neuropeptide $\mathrm{Y}$ (NPY)/agouti-related peptide (AgRP) neurons in the hypothalamic arcuate nucleus (ARC) that result in increased food intake. In contrast, leptin level drops down during starvation and also stimulates appetite, as low leptin signaling blocks the activity of anorexigenic pro-opiomelanocortin (POMC)/cocaine and amphetamine-regulated transcript (CART) neurons and concomitantly enhances orexigenic NPY/AgRP release in the ARC (Valassi et al., 2008). Most studies agree that during inflammatory anorexia-cachexia syndrome ghrelin levels are upregulated while leptin down-regulated, but food intake is not increased (Laviano et al., 2008).

Our studies have shown that rats with chronic inflammatory arthritis associated with anorexia had increased ghrelin and decreased leptin plasma levels along with overexpression of orexigenic neuropeptide (NPY, AgRP) mRNAs and decreased mRNA expressions of anorexigenic neuropeptide CART in the ARC (Stofkova et al., 2009b, 2010). However, we did not observe any improvement in food intake or body mass in this chronic inflammatory condition (Stofkova et al., 2009b; 2010). Similar situation has occurred in tumor-bearing rats with anorexia-cachexia syndrome. Hashimoto and coauthors (2007) have 
demonstrated increased NPY/AgRP and decreased CART mRNAs in the ARC as well as reduced circulating leptin levels that have not been associated with the amelioration of cachectic symptoms. It appears that the mechanisms evolved to maintain energy balance are not sufficient enough to suppress anorexia in chronic inflammatory burden. This could involve negative interference of pro-inflammatory signals with protein synthesis or release of orexigenic neuropeptides. In this context, Scarlett and colleagues (2008) have observed that pro-inflammatory signals decrease the secretion of AgRP from hypothalamic explants, while increasing the expression of AgRP mRNA in hypothalamus in rodent models of acute and chronic inflammation.

Remarkably, food restriction may attenuate the catabolic response of inflammation. It is well documented that IL-1 $\beta$ - or acute inflammation-induced anorexia can be reduced by prior food restriction (Mrosovsky et al., 1989; Kent et al., 1994; Lennie et al., 1995, 1998; Elander et al., 2007). Similarly, $48 \mathrm{~h}$ fast in rats reduced lipopolysaccharide (LPS)-induced Fos expression in the paraventricular nucleus of the hypothalamus (PVN), increased orexigenic NPY and decreased anorexigenic CART mRNAs in the ARC, in association with attenuation of anorexia and body weight loss (Gautron et al., 2005). In our study, food-restriction in arthritic rats led to a more profound decrease of mRNA expressions for anorexigenic factors (POMC, CART, IL-1 $\beta$ ) and marked increase of mRNA expressions for orexigenic factors (NPY, AgRP) in the ARC when compared to arthritic rats fed ad libitum (Stofkova et al., 2010). Moreover, food restriction in rats with adjuvant arthritis decreased arthritic score and parameters of inflammation including plasma leptin, but up-regulated plasma ghrelin and corticosterone levels (Jurcovicova et al., 2001; Stofkova et al., 2010). Accordingly, mild starvation through alterations in leptin and ghrelin levels may have protective antiinflammatory effects on signaling pathways in the hypothalamus that lead to conservation of body energy and favoring the foraging behavior.

It is worth noting that ghrelin and leptin mutually cooperate not only in the regulation of energy balance but also in the control of immune responses. Ghrelin is considered as an anti-inflammatory hormone since it inhibits expression of pro-inflammatory cytokines such as IL-1 $\beta$, IL-6 and TNF-a (Dixit et al., 2004). Ghrelin has also been reported as a potent mediator of lymphocyte development in the primary lymphoid organs and was able to reverse age-associated thymic involution. A number of studies over the past decade have described ghrelin as a promising therapeutic agent in the treatment of inflammatory diseases. Ghrelin administration attenuated anorexia as well as inflammation and rate of mortality during endotoxin- or IL-1 $\beta$-induced inflammation (Chang et al., 2003; Gonzalez et al., 2006; Wu et al., 2007; Chorny et al., 2008). In chronic inflammation, treatment with ghrelin significantly ameliorated experimental colitis in mice and rats (Gonzalez-Rey et al., 2006; Konturek et al., 2009), chronic kidney disease in rats (Deboer et al., 2008) or experimental autoimmune encephalomyelitis in mice (Theil et al., 2009) due to its inhibitory effect on pro-inflammatory cytokines. In experimental arthritis in rats, ghrelin treatment significantly reduced clinical signs of the disease as well as the release of the high mobility box 1 (HMGB1), a DNA-binding factor that acts as a late inflammatory factor (Chorny et al., 2008). Similarly, Granado et al. (2005a) observed ameliorated external symptoms of adjuvant arthritis in rats along with decreased IL-6 serum levels after ghrelin agonist (GHRP-2) administration. Moreover, GHRP-2 also prevented the increase in the activity of the ubiquitin-proteasome proteolytic pathway involved in the cachexia-induced skeletal muscle atrophy of arthritic rats (Granado et al., 2005b). 
Leptin is cytokine-like hormone structurally classified as a member of the long-chain helical cytokine family, which also includes IL-6, IL-11, IL-12 or leukemia inhibitory factor (LIF). It stimulates proliferation of the majority of immune cells, and on memory $\mathrm{T}$ cells leptin promotes the switch towards Th1-cell immune responses by increasing interferon-gamma (IFN- $\gamma$ ) and TNF-a secretion while suppresses Th2-cell immune responses producing IL-4 and IL-10. Leptin may play an important role in pathogenesis of autoimmunity as leptindeficient mice are resistant to (or develop less severe) experimental Th1-mediated autoimmune diseases (Stofkova, 2009a). Notably, a decrease in serum leptin levels induced by acute starvation led to a delay of the onset of experimental autoimmune encephalomyelitis and attenuated clinical symptoms by promoting a Th2-mediated cytokine switch (Sanna et al., 2003). Furthermore, in patients with rheumatoid arthritis, reduced circulating leptin levels due to 7-day fast were associated with decreased CD4+ T-cell activation and an increased number and function of IL-4-producing Th2 cells that resulted in attenuation of measurements of the disease activity (Fraser et al., 1999).

These findings indicate that during inflammatory anorexia low leptin and high ghrelin levels may represent an attempt of endocrine system to increase food intake and to turn off the activated immune system. A short period of mild starvation could intensify these compensatory mechanisms and could be beneficial in certain autoimmune or chronic inflammatory conditions (e.g., where hyperleptinemia is a detrimental factor). However, usefulness of starvation regime in other inflammatory diseases should be considered carefully depending on actual nutritional status of patients and the severity of cachexia syndrome.

\section{The role of cytokines in the central control of appetite}

Several studies have provided important insight into the complex effects of cytokines on brain functions including the generation of the anorectic response. The cytokine that was initially held responsible for causing anorexia-cachexia syndrome was TNF, but it was soon clarified that the action of TNF can only be understood in the context of simultaneous presence of other cytokines (Matthys \& Billiau, 1997). A number of cytokines such as IL-1a, IL-1 $\beta$, IL-2, IL-6, IL-8, IL-11, IL-18, IFN- $\alpha$, IFN- $\gamma$, LIF, ciliary neurotrophic factor (CNTF), brain-derived neurotrophic factor (BDNF), granulocyte macrophage colony-stimulating factor (GM-CSF), fibroblast growth factor (FGF), and HMGB-1 has been shown to inhibit food intake after central or peripheral administration at least equally powerfully as TNF (Buchanan \& Johnson, 2007). For instance, when TNF-a was administered individually it had less potent anorectic effects than those of IL-1 $\beta$ or when co-administered with IL-1 $\beta$ (Sonti et al., 1996). IL-6 also inhibits food intake when administered centrally but not peripherally. Nevertheless, IL-6 deficient mice showed attenuated suppression of food intake during acute inflammation (Buchanan \& Johnson, 2007). IL-1 $\beta$ is a potent anorexigenic cytokine when administered peripherally or centrally in rodents, and treatment with IL-1 $\beta$ antagonists can completely prevent IL-1 $\beta$-induced anorexia (Rothwell \& Luheshi, 1994; Kent et al., 1992). Furthermore, peripheral IL-1 $\beta$ through the interactions with IL-1 receptor also induces inhibition of gastric emptying and motility that can exacerbate hypophagia in patients with anorexia-cachexia syndrome (Suto et al., 1996). Central or peripheral injection of IFN- $a$ also leads to a decrease in food intake that correlates with a depression of the lateral hypothalamus neuronal electrical activity (Reyes-Vazquez et al., 1994). 
It is well established that systemic inflammation during microbial infections, cell injury, autoimmunity or cancer triggers an excessive production of pro-inflammatory cytokines. But since hypothalamus is the main site regulating feeding behavior and body weight, cytokines must reach the brain regions to initiate anorexia. However, the blood brain barrier (BBB) which is composed by endothelial cells of the cerebral blood vessels joined by tight junctions is impenetrable for cytokines. So how can they get there and trigger anorexia when the inflammation is of peripheral origin?

There were described three possible pathways that may account for cytokine-induced anorexia after peripheral inflammation: 1) a humoral pathway by which cytokines reach the central nervous system via blood (direct actions on circumventricular structures characterized by the absence of the BBB); 2) a pathway that involves active transport of cytokines across the $\mathrm{BBB}$ or their binding to the luminal side of the blood vessels and induction of the production of immunomodulators (prostaglandins, nitric oxide) that can easily cross the BBB, and central de novo synthesis of cytokines (e.g. in microglial cells and astrocytes); and 3) transduction by a neural pathway from gut to the brain, via sensory vagal or non-vagal, splanchnic afferents (Schwartz et al., 2002; Grossberg et al., 2010).

Peripheral administration of LPS has been used as a good model demonstrating that peripheral inflammation induces expression of cytokines including IL-1 $\alpha$, IL-1 $\beta$, IL-6, TNF- $\alpha$ and LIF in the brain. In addition, it was observed that these cytokines can further propagate and maintain their activity by stimulating their own production and simultaneously the production of other cytokines in the brain (Grossberg et al., 2010). Although, this situation occurs after a single LPS injection, recent studies have reported that the following injection of LPS has brought about protective anti-inflammatory effects within the brain. Intriguingly, immunological challenge with the endotoxin LPS three weeks after a first LPS injection resulted in attenuated hypothalamic expression of cytokines while splenic expression was elevated (del Rey et al., 2009). On the basis of these findings, it seems that modulation of central cytokine expression may involve an adaptive mechanism protecting the brain from augmentation of inflammatory signaling and subsequent neuronal damage or behavioral and neuroendocrine changes (del Rey et al., 2009).

Increased expression of pro-inflammatory cytokines in the brain has also been reported in experimental models of chronic diseases associated with anorexia including colitis (El-Haj et al., 2002; K. Wang et al., 2010), cancer (Plata-Salaman et al., 1998) and arthritis (Stofkova et al., 2009b, 2010). Yet, there are some contradictory findings showing no differences in brain cytokine (IL-1 $\beta$, IL-6, TNF- $\alpha$ ) protein expressions among tumor-bearing mice with prostanoid-related anorexia and their pair-fed controls (W. Wang et al., 2001).

Notwithstanding, there is no doubt that central inflammation plays a pivotal role in anorexia associated with infections or chronic inflammatory diseases. Importantly, the anorexigenic effects of LPS or IL-1 $\beta$ were eliminated in the absence of central myeloid differentiation primary response gene 88 (MyD88), the primary inflammatory intracellular signal transduction pathway for type I IL-1 receptor (IL-1RI) and toll-like receptor 4 (TLR4), that activates the transcription factor nuclear factor-kappaB (NF-kB) (Ogimoto et al., 2006; Wisse et al., 2007b). Moreover, central inhibition of NF-KB pathway by a specific inhibitor the NEMO (Binding Domain (NBD) peptide), which completely abolishes COX-2 synthesis in response to IL-1 $\beta$ in the brain microvasculature, significantly blocked the inflammatory anorectic behavior (Nadjar et al., 2005).

IL-1 $\beta$ has been the most studied cytokine in relation to anorexia-cachexia syndrome. Its key role in the development of inflammatory anorexia was documented in experimental models 
of cancer and colitis, in which neutralization of IL-1 $\beta$ significantly improved food intake (Laviano et al., 2000; El-Haj et al., 2002).

Several studies have attempted to clarify the possible mechanism through which IL-1 $\beta$ elicits anorexia. Since IL-1 $\beta$ dose-dependently up-regulates leptin expression in adipose tissue, and leptin decreases food intake and body weight, it was thought that IL-1 $\beta$ anorectic effect is mediated via leptin activation. However, IL-1 $\beta$ is able to induce anorexia independently from leptin activation, as it was shown in animal models with severely attenuated leptin signaling (Faggioni et al., 1997; Lugarini et al., 2005). On the other hand, there have been proposals that leptin besides activating the anorexigenic neuropeptides may also mediate anorexigenic responses via actions dependent on release of IL-1 and prostaglandins in the brain. Interestingly, it has been reported that central injection of IL-1 receptor antagonist (IL-1ra) inhibited the suppression of food intake caused by central or peripheral injection of leptin. Consonantly, IL-1RI knockout mice showed no reduction in food intake in response to leptin (Luheshi et al., 1999), and lack of IL-1RI-mediated biological activity caused mature-onset obesity (Garcia et al., 2006). However, there is controversy on the importance of the hypothalamic IL-1 for the physiological regulation of food intake by leptin. It appears that central IL-1 signaling is required for the pharmacological, but not physiological, effects of leptin on energy balance (Wisse et al., 2007a).

Recent studies have demonstrated that IL-1 $\beta$ suppresses appetite directly by the activation of central melanocortin system through its receptor IL-1RI abundantly expressed in neurons regulating appetite (DeBoer \& Marks, 2006; Scarlett et al., 2007, 2008). The central melanocortin system forms the populations of POMC- and AgRP-expressing neurons in the $\mathrm{ARC}$ and the brainstem neurons in the nucleus tractus solitarius (Grossberg et al., 2010). POMC is the precursor of melanocortin peptides including a-melanocyte stimulating hormone (a-MSH), which exerts anorexigenic effects by acting on central melanocortin receptors (MCRs) (Fan et al., 1997). In the brain, only the type-3 melanocortin receptors (MC3R) and type-4 melanocortin receptors (MC4R) have been found. The most important one through which a-MSH inhibits appetite is MC4R and this receptor is mainly expressed in the PVN. The neuropeptide AgRP is an endogenous antagonist at melanocortin receptors and majority of AgRP neurons project to MC4R-expressing neurons (Ollmann et al., 1997; Grossberg et al., 2010).

An intracerebroventricular (i.c.v.) injection of IL-1 $\beta$ into the lateral ventricles activated expression of Fos protein in the ARC POMC neurons resulting in the inhibition of feeding behavior. In addition, IL-1 $\beta$ stimulated the release of a-MSH from hypothalamic explants (Scarlett et al., 2007). Additionally, IL-1 $\beta$ has been shown to decrease secretion of AgRP from the hypothalamus (Scarlett et al., 2008). The hypothesis that IL-1 $\beta$ acts through central melanocortin signaling also supports the finding that anorectic effect of IL-1 $\beta$ was significantly attenuated by MC3/4-R antagonists (Lawrence \& Rothwell, 2001).

It is very likely, that IL-1 $\beta$ (and other cytokines) interacts with hypothalamic serotonergic neurons to activate pathways of central melanocortin system (Laviano et al., 2008). Serotonin, a monoamine neurotransmitter derived from tryptophan, modulates behavioral reactions and various physiological processes. The important role of serotonin has also been defined in relation to satiety (Leibowitz et al., 1990). The serotonergic regulation of energy balance comprises the modulation of the endogenous release of both agonists and antagonists of the melanocortin receptors. Serotonin hyperpolarizes and inhibits AgRP neurons as well as decreases an inhibitory drive onto POMC cells by activation of serotonin 
$1 \mathrm{~B}$ receptors (5-HT1BRs). Serotonin also activates POMC neurons via activation of serotonin $2 \mathrm{C}$ receptors (5-HT2CRs). This leads to reciprocal increases in a-MSH release and decreases in AgRP release at MC4R in target sites and subsequently to hypophagia (Heisler et al., 2006). Increased serotonin release associated with depressed food intake has been found after an injection of IL-1a into ventromedial hypothalamic nucleus in normal rats (Yang et al., 1999). During cachexia IL-1 increases levels of tryptophan in the plasma and cerebrospinal fluid, thereby suggesting increased serotonin synthesis and secretion (Tijerina, 2004; Laviano et al., 2008). These findings indicate that both IL-1 and serotonin are important factors involved in the pathogenesis of anorexia-cachexia syndrome.

CNTF and LIF are another cytokines that possess anorectic effects through influencing POMC neurons in the hypothalamus via gp130/signal transducer and activator of transcription 3 (STAT3) signaling pathway (Janoschek et al., 2006, Grossberg et al., 2010). Moreover, in the murine hypothalamus, CNTF induces proliferation of cells that show functional phenotypes relevant for energy-balance control, including a capacity for leptininduced phosphorylation of STAT3 (Kokoeva et al., 2005). CNTF has also been shown to suppress NPYergic signaling in the hypothalamus by direct action (parallel to leptin) on NPY neurons (Xu et al., 1998). In contrast, within the hypothalamic orexigenic NPY system, neither IL-1 $\beta$ nor TNF- $\alpha$ and IL-6 was able to alter NPY release from the hypothalamic slices (King et al., 2000). Similarly, in IL-1 $\beta$-treated and pair-fed group rats, there were unchanged NPY concentrations in the ARC (McCarthy et al., 1995). Beyond these results, other studies have shown that NPY i.c.v. administration blocks and reverses IL-1 $\beta$ - or INF- $\alpha$-induced anorexia (Sonti et al., 1996; Turrin et al., 1999). Therefore, the interactions between cytokines and orexigenic NPY system in the pathogenesis of inflammatory anorexia remain to be elucidated.

\section{The role of cytokines in the muscle catabolism}

Muscle wasting is another debilitating complication found in variety of cachectic states such as cancer, sepsis, chronic heart failure, chronic kidney disease, rheumatoid arthritis, COPD, and AIDS (Glass \& Roubenoff, 2010). The primary cause of muscle wasting is the systemic inflammatory response that leads to accelerated muscle proteolysis, decreased muscle protein synthesis, impaired muscle progenitor cell proliferation, or increased apoptosis of muscle cells. Most research papers suggest that the main catabolic factors responsible for these pathological processes are cytokines. But which ones are the main candidates? What are the similarities and differences among their actions? What are the critical pathways that are affected?

In the last decade skeletal muscle has been identified as an endocrine organ that produces and releases cytokines and other peptides, so-called "myokines" (Pedersen \& Febbraio, 2008). It is well established that these myokines modulate muscle cell viability, growth, differentiation and finally death as well as exert their effects in other organs of the body. They can be synthesized and released not only from immune cells infiltrating skeletal muscles (e.g. during exercise) but also by muscle fibers per se (Pajak et al., 2008). Among a wide group of myokines should be named pro-inflammatory cytokines such as TNF-a, IL-1 $\beta$, IL-6, IL-8, IL-15, IFN- $\gamma$, CNTF, LIF, or TGF- $\beta$ (Pajak et al., 2008; Hunt et al., 2011; Burks \& Cohn, 2011; Stockli et al., 1989; Cheng et al., 2008; Pedersen \& Febbraio, 2008).

Cytokines act on skeletal muscle cells through the specific membrane receptors that may differ for each cytokine in their intracellular domains and thus mediate distinct cellular 
responses. For instance, IL-1 has two unique receptors on target cells: The type I receptor (IL-1RI) transduces a signal, whereas the type II receptor (IL-1RII) binds IL-1 but does not transduce a signal and has been named a "decoy" receptor (Dinarello, 1996). Sarcolemma of the skeletal muscle was found to express very low levels of cytokine receptors under normal (resting) physiological conditions, but has a capacity for cytokine receptor induction and thereby amplification of cytokine actions in response to exercise and inflammatory stimuli such as endotoxin or increased level of cytokine itself. As for the inflammation, treatment of L6 myotubes with a combination of endotoxin, TNF- $\alpha$, and IFN- $\gamma$ for $24 \mathrm{~h}$ led to the increased mRNA expression of six pro-inflammatory cytokine receptors (IL-1RI, IL-1RII, IL-6 receptor (IL-6R), IFN receptor IFNR, TNF receptor (TNFR)I, TNFRII), whereas TNF alone induced expression of only IL-6R and TNFRII mRNAs (Y. Zhang et al., 2000). The TNF-a receptor TNFRI contains a cytoplasmic TNFR-associated death domain (TRADD), which is essential for activation of the caspase cascade and subsequently induction of apoptosis. However, TNFRI signaling provides also a mechanism to protect cells from an apoptotic response since TRADD can associate with TNFR-associated factor (TRAF)2, TRAF1 and receptor interacting protein (RIP) to activate the NF- $\mathrm{kB}$ and c-Jun N-terminal kinase (JNK) pathways, which protect cells from apoptosis. The second TNF-a receptor TNFRII misses the death domain and contains TRAF-interacting motifs (TIMs) in their cytoplasmic domain. Activation of TIM leads to the recruitment of TRAF family members and the subsequent activation of signal transduction pathways like NF-kB, JNK, p38, extracellular signal-related kinase (ERK) and phosphoinositide 3-kinase (PI3K) (Hehlgans \& Pfeffer, 2005). The NF-KB is an essential mediator for protein degradation and expression of the ubiquitin-proteasome system, the major pathway for breakdown of muscle contractile proteins leading to muscle loss (Lecker et al., 1999; Y.P. Li \& Reid, 2000). Likewise the activation of the ubiquitin-proteasome system is vital for ubiquitination and degradation of $\mathrm{I} \mathrm{KB}$, an inhibitory protein that binds the NF- $\mathrm{KB}$ and retains this factor in the cytoplasm where it cannot activate gene expression of a number of inflammatory peptides (Z.J. Chen, 2005). The NF-kB-induced proteolysis in cachectic syndrome provides the energy supply for the stimulated immune system. The products of proteolysis amino acids are transported to the liver where they are an important substrate for gluconeogenesis, but also are consumed in synthesis of acute phase proteins such as C-reactive protein (CRP) and serum amyloid A (Morley et al., 2006).

Among a variety of stimuli, TNF- $\alpha$ is one of the most potent activators of NF-kB (Pajak et al., 2008). TNF-a has been shown to induce the ubiquitin-proteasome system dependent proteolysis after its acute intravenous administration in rats, or in vitro in isolated rat soleus muscle (Garcia-Martinez et al., 1993, 1994; Llovera et al., 1997). This direct effect of TNF-a on the muscle cell is mediated not only through the activation of NF-kB (Y.P. Li et al., 1998; Y.P. Li \& Reid, 2000), but also various other signal transduction pathways. Sishi \& Engelbrecht (2011) have reported that TNF-a strongly potentiated its proteolytic effects through certain mitogen-activated protein kinases (MAPKs), or PI3-K/Akt pathway resulting in decreased muscle fiber diameter. Furthermore, when differentiated L6 myotubes were subjected to increasing concentrations of recombinant TNF-a for 24 and $48 \mathrm{~h}$, an up-regulated expression of E3 ubiquitin ligases MuRF-1 (muscle RING finger 1) and MAFbx (muscle atrophy F-box; also called artrogin-1) along with the transcription factors NF-kB and forkhead transcription factor (FKHR; also called forkhead box protein O1 (FOXO1)) were observed (Sishi \& Engelbrecht; 2011). FKHR is the other principal factor involved in muscle atrophy and activation of ubiquitin-proteasome proteolytic pathway (Tisdale, 2007). The important role of TNF-a in muscle wasting has also been proved by the anti-TNF treatment in situation 
when TNF production rises. In tumor-bearing rats or septic rats, the anti-TNF treatment powerfully inhibited muscle wasting by blocking the enhanced ubiquitin-proteasome dependent proteolysis (Costelli et al., 1993; Combaret et al., 2002).

Besides influencing the activity of the ubiquitin-proteasome system and subsequently muscle proteolysis, TNF- $\alpha$ also affects muscle differentiation by interaction with MyoD gene expression. MyoD is a crucial transcriptional factor that is required for the differentiation of muscle stem cells, and it functions early in myogenesis to help stem cells proliferate in response to muscle injury (K. Zhang et al., 2010). It has been shown that TNF-induced activation of NF- $\mathrm{kB}$ in differentiating $\mathrm{C} 2 \mathrm{C} 12$ myocytes inhibited skeletal muscle differentiation by suppressing MyoD mRNA at the posttranscriptional level. In differentiated myotubes, TNF plus IFN- $\gamma$ signaling was required for NF-kB-dependent down-regulation of MyoD and dysfunction of skeletal myofibers. The same results have also been observed in mouse muscle in vivo (Guttridge et al., 2000). Additionally, increased TNF/IFN signaling repressed the expression of myosin heavy chain at the transcriptional level, possibly resulting from the cytokine-mediated inhibition of MyoD synthesis (Acharyya et al., 2004). TNF-a may also inhibit myogenesis through induction of the nitric oxide synthase gene (iNos). Increased nitric oxide conjugates with superoxide to form peroxynitrite, which is responsible for the down-regulation of MyoD mRNA. It appears that TNF-a exhibits a dual effect on myogenesis, stimulating it at low concentrations (0.05 $\mathrm{ng} / \mathrm{ml})$, while inhibiting it at higher concentrations $(0.5$ and $5 \mathrm{ng} / \mathrm{ml})$ (Tisdale, 2008).

The next mechanism through which TNF-a promotes muscle wasting is depression of muscle protein synthesis. This depression is mediated at least in part by defects in the control of mRNA translation (Lang et al., 2002). Moreover, when TNF- $\alpha$ and IFN- $\gamma$ were presented in the extracellular environment during $\mathrm{C} 2 \mathrm{C} 12$ myoblast differentiation, they prevented the stimulatory action of insulin-like growth factors I (IGF-I) on protein synthesis. This effect of TNF-a and IFN- $\gamma$ was associated with the decreased phosphorylation of serine/threonine protein kinases, protein kinase B (PKB/Akt) and p70S6 kinase, in C2C12 myogenic cells (Grzelkowska-Kowalczyk \& Wieteska-Skrzeczynska, 2010). Inhibition of muscle IGF-I production could be another mechanism contributing to the catabolic effect of TNF-a since an increase of this cytokine in muscle after LPS injection significantly inhibited local IGF-I expression (Fernandez-Celemin et al., 2002).

Finally, exposure of $\mathrm{C} 2 \mathrm{C} 12$ myotubes to TNF-alpha induces apoptosis characterized by enhanced caspase-3 activity, which results in poly(ADP-ribose) polymerase (PARP) cleavage and increased histone-associated-DNA fragmentation. Although IFN- $\gamma$ was proposed as a pro-cachectic factor, it reversed the TNF-a-induced apoptotic activity (Tolosa et al., 2005). In line with this finding, Cheng et al. (2008) have demonstrated that IFN- $\gamma$ promotes muscle healing, in part, by stimulating formation of new muscle fibers. Administration of an IFN- $\gamma$ receptor blocking antibody to wild-type mice impaired induction of IFN response factor-1, reduced cell proliferation, and decreased formation of regenerating fibers. Additionally, IFN- $\gamma$ null mice showed similarly impaired muscle healing associated with impaired macrophage function and development of fibrosis (Cheng et al., 2008). In contrast, a transgenic mouse that constitutively overexpresses IFN- $\gamma$ at the neuromuscular junction demonstrated an age-dependent necrotizing myopathy (Shelton et al., 1999). According to contradictory findings on functions of IFN- $\gamma$ in skeletal muscle homeostasis, the possible therapeutic potential of IFN- $\gamma$ targeting is still illusive.

Other cytokines generally accepted as mediators of muscle proteolysis are IL-1 and IL-6 (Zamir et al., 1992, 1993; Authier et al., 1997; Goodman, 1994). In vitro studies confirmed 
that IL-1 $\alpha$ and IL-1 $\beta$ are able to stimulate muscle catabolism via NF- $\mathrm{KB}$ signaling leading to an increased expression of atrogin-1/MAFbx and MuRF-1, and reduced myofibrillar protein content (W. Li et al., 2009). However, in vivo studies showed that catabolic effects of IL-1 are not as severe as those of TNF- $\mathrm{a}$. Although the treatment with recombinant IL-1ra prevented muscle proteolysis induced by administration of IL-1, this treatment only reduced, but did not normalize, the increased muscle protein breakdown rates seen during sepsis in rats (Zamir et al., 1994). Further, an acute intravenous administration of $100 \mu \mathrm{g} / \mathrm{kg}$ body weight of human recombinant TNF-a resulted in an important increase in the levels of ubiquitin mRNAs in rat skeletal muscle, whereas administration of a similar amount of human recombinant IL-1 $\beta$ did not (Garcia-Martinez et al., 1995). Also, administration of IL-1ra to tumor-bearing rats did not result in any improvement of cachexia, thus suggesting that the role of IL-1 in muscle cachexia may be secondary to the actions of other mediators (Argiles et al., 2005). Regarding IL-6, it was reported that IL-6 was the only pro-inflammatory cytokine of the six cytokines measured that was elevated in all terminally ill cancer patients with cachexia and its levels rise just before death (Iwase et al., 2004). Elevated circulating IL-6 level associated with reduced muscle oxidative capacity, mitochondria dynamics, and markers of oxidative stress in both oxidative and glycolytic muscles and with severe wasting have been found in Apc(Min/+) mice, a model of human colon cancer (White et al., 2011). An increased atrogin-1/MAFbx, but not MuRF-1, gene and protein expression were also observed in these mice, and when they were exposed to IL-6 overexpression, atrogin-1/MAFbx mRNA and protein levels were up-regulated. However, atrogin1/MAFbx mRNA increased too little and did not translate to protein in wild-type noncachectic mice after IL-6 overexpression. Consistently, it was observed that without underlying disease IL-6 induces body mass or skeletal muscle mass loss only in supraphysiological doses. It is also possible, that IL-6 stimulates muscle cachexia indirectly as a lipolytic agent inducing a release of lipid from adipose tissue stores, and this state of hyperlipidemia is detrimental for skeletal muscle (Carson \& Baltgalvis, 2010).

The IL-6-related cytokine LIF may be involved in the pathogenesis of heart failure since it has been shown to reduce contractile function and to induce alterations in energy metabolism and insulin sensitivity in isolated cardiomyocytes. Moreover, the presence of this cytokine has been found in failing hearts (Florholmen at al., 2004, 2006). In skeletal muscle LIF has been shown to be a critical factor for TNF-a-induced inhibition of myoblast differentiation (Alter et al., 2008).

Although most pro-inflammatory cytokines are negatively involved in muscle wasting during inflammatory diseases or cancer, IL-15 may be an example of compensatory effects of activated immune system on muscle homeostasis. IL-15 is a cytokine with structural similarity to IL-2 that exhibits a broad range of pro-inflammatory activities including induction of $\mathrm{T}$ and $\mathrm{B}$ cell proliferation, NK cell cytotoxicity and NK-cell-derived cytokines (IFN- $\gamma$, granulocyte-macrophage colony stimulating factor (GM-CSF), TNF- $\alpha$ ), and may protect T cells and neutrophils from apoptosis (Argiles et al., 2009). Nevertheless, IL-15 is a cytokine which is highly expressed in skeletal muscle and has been shown to have anabolic effects. Quinn et al. (1995) have reported that IL-15 can stimulate differentiated myocytes and muscle fibers to accumulate increased amounts of contractile proteins. Furthermore, overexpression of IL-15 induced skeletal muscle hypertrophy accompanied by increased levels of sarcomeric myosin heavy chain and alpha-actin in the culture of differentiated myotubes. In contrast to well-known anabolic factor IGF-I, which only stimulates protein synthesis under these culture conditions, IL-15 stimulates protein synthesis as well as 
inhibits protein degradation (Quinn et al., 2002). In vivo studies demonstrated that IL-15 administration improves the pathophysiology of dystrophic muscle in mice (Harcourt et al., 2005) as well as cachectic muscle in rats bearing the Yoshida AH-130 ascites hepatoma (Carbo et al., 2000; Figueras et al., 2004). The possible mechanism through which IL-15 mediates its anabolic effects is an inhibition of the ATP-ubiquitin-dependent proteolytic pathway as described Carbo et al. (2000), and/or a decrease in both TNF-alpha receptors TNFRI and TNFRII, and iNos protein levels as described Figueras et al. (2004). Recently Waldmann et al. (2011) performed a safety study in rhesus macaques that received recombinant human IL-15. Interestingly, IL-15 mediated neutrophil redistribution from the circulation to tissues, increased numbers of circulating NK and CD8 central and effectormemory $\mathrm{T}$ cells. These findings suggest that IL-15 might represent a new immunomodulatory and anabolic tool for the treatment of cachexia associated with metastatic malignancies (Waldmann et al., 2011). However, the potential application of IL-15 in other conditions associated with inflammatory cachexia syndrome should be carefully evaluated because IL-15 is also proposed as an important factor in pathogenesis of several chronic inflammatory diseases such as rheumatoid arthritis (Petrovic-Rackov \& Pejnovic, 2006). Contradictory findings have been obtained in possible involvement of IL-15 in sarcopenia, the degenerative loss of skeletal muscle mass and strength associated with aging, in rats. Though one study has shown that preservation of IL-15 signaling by caloric restriction is associated with mitigated loss of muscle mass (Marzetti et al., 2009), other study has described that treatment with IL-15 promotes apoptosis in skeletal muscle and decreases muscle mass in both young adult and aged rats (Pistilli \& Alway, 2008).

Other interesting anabolic cytokine could be anti-inflammatory IL-10 that restrains inflammatory responses in macrophages and $\mathrm{T}$ cells by inhibiting cytokine and chemokine synthesis and reducing expression of their receptors. This cytokine is able to prevent inflammatory muscle wasting since it suppresses the ability of exogenous IL-1 $\beta$ to inhibit IGF-I-induced myogenin and myosin heavy chain expression in myoblasts by specific reversal of IL-1 $\beta$ activation of the JNK kinase pathway. Thus IL-10 may be useful therapeutic approach to inhibit the IL-1 $\beta$ receptor-induced JNK kinase pathway resulting in IGF-I resistance (Strle et al., 2008).

\section{The role of cytokines in the insulin resistance and changes in intermediary metabolism}

Impaired insulin sensitivity is another symptom frequently present during cachexia in humans and animal models (Crossland et al., 2008; Smiechowska et al., 2010; Asp et al., 2010; Doehner et al., 2010). This metabolic disorder also develops due to the excessive activation of inflammatory pathways. It is well established that TNF- $\alpha$ is a potent activator of JNK and I kappa beta kinase (IKK) that phosphorylates insulin receptor substrate (IRS) proteins at inhibitory serine (Ser) sites and thereby inactivates further transmission of the insulin signal (Hotamisligil, 2003). In fact, when five potential inhibitory Ser sites of IRS were mutated, the protection from the adverse effects of pro-inflammatory cytokines (IL-1 $\beta$, TNF- $\alpha$, and IFN- $\gamma$ ) and improvement of $\beta$-cell survival and function were observed (Gurevitch et al., 2010). Other inflammatory mediators that interact with IRS phosphorylation are suppressors of cytokine signaling (SOCS)- 1 and SOCS-3 that decrease tyrosine (Tyr) phosphorylation of IRS, which is essential for transmission of insulin signal (Ueki et al., 2004). Importantly, IL-6 inhibits insulin action in liver, but not in muscle, by 
both phosphorylation of the inhibitory Ser site of IRS-1 and induction of SOCS-3 expression (Weigert et al., 2006).

The key role of inflammation in the development of insulin resistance also demonstrate findings that the inhibition of TNF-a activity either chemically or genetically results in improved insulin sensitivity (Hotamisligil, 2003), and application of nonsteroidal antiinflammatory drugs enhances insulin sensitivity (Donath et al., 2005).

It is important to note, that pro-inflammatory cytokines may blunt not only insulin signaling but also IGF-I signaling since IRS proteins are important substrates for IGF-I receptor as well. IGF-I increases muscle protein synthesis and activates functions of satellite cells, the quiescent stem cells in adult muscle, which act as a reserve population of cells, able to proliferate in response to injury and give rise to regenerated muscle (Morgan \& Partridge, 2003). With this regard, impaired IGF-I signaling leads to abnormal protein metabolism and promotes fibrosis in regenerating muscle as recently reported L. Zhang et al. (2010) in cachectic mice with chronic kidney disease. It seems that particularly relevant cytokine in impaired insulin/IGF-I signaling during chronic kidney disease could be IL-6 since cachectic response to angiotensin II was suppressed in IL-6-deficient mice. Indeed, angiotensin II promotes the release of IL-6 and serum amyloid A, and these two mediators act synergistically to impair insulin/IGF-I signaling in muscle that subsequently results in muscle proteolysis (L. Zhang et al., 2009).

Because impaired insulin/IGF-I signaling decreases muscle protein synthesis, one cannot ignore the obvious implication, that insulin resistance may be a cause rather than a consequence of muscle cachexia. From this point of view, it has been shown that in mice with cachexia induced by colon-26 tumors, insulin resistance occurred before the onset of weight loss, and treatment with rosiglitazone, a peroxisome proliferator-activated receptorgamma (PPARY) agonist and potent insulin action-enhancing agent, improved insulin sensitivity and also led to the reduction of early markers of cachexia and increase in body weight (Asp et al., 2010). These results suggest that correction of insulin resistance may provide a new therapeutic approach for cachexia and further research is needed to define the role of insulin resistance in variety of catabolic diseases.

Besides the impact of cytokines on insulin resistance, free fatty acids (FFA) are other crucial mediators that contribute to this pathological condition (Boden, 2001). Noticeably, derangements in lipid metabolism are common features of many chronic diseases accompanied by cachexia (Grunfeld \& Feingold, 1992; Vaziri \& Norris, 2011; Elkan et al., 2009; Rauchhaus et al., 2000). Although the most obvious cause of secondary dyslipidemia is a sedentary lifestyle with excessive dietary intake of saturated fat, cholesterol and trans fats, the corroborating evidence indicate that during cachexia the key players of the changes in lipid metabolism are inflammatory cytokines along with counter-regulatory hormones released in response to cytokine activity, such as glucocorticoids and catecholamines (Morley et al., 2006; Grunfeld \& Feingold, 1992; Memon et al., 1993; Feingold et al., 1994; Rauchhaus et al., 2000). Approvingly, the response to LPS is associated with TNF- and IL-1induced increase in serum cholesterol and triglyceride levels as well as increase in hepatic hydroxy-3-methylglutaryl-coenzyme A (HMG-CoA) reductase activity in mice (Memon et al., 1993). In mice, LPS also decreases the activity of lipoprotein lipase (LPL), the enzyme responsible for plasma triglyceride clearance, in both adipose and muscle tissue. This effect of LPS was suggested to be mediated by cytokines such as TNF, IL-1, LIF, IFN-a, and IFN-ץ, depending upon type of tissue. In intact mice, all these cytokines down-regulated LPL activity in adipose tissue, while in skeletal and cardiac muscle only IL- 1 and IFN- $\gamma$ followed 
this effect. However, inhibition of TNF or IL-1 activity did not affect the ability of LPS to decrease adipose tissue or muscle LPL activity, indicating that mechanisms underlying LPS actions on lipid homeostasis are complex and several inflammatory signals might be involved (Feingold et al., 1994).

Furthermore, it has been shown that TNF-a stimulates synthesis of free fatty acids (FFA) de novo in the liver through raising levels of citrate and suppression of liver peroxisomal $\beta$ oxidation by inhibiting the activity of peroxisomal fatty acyl-CoA. In adipose tissue TNF- $\alpha$ increases lipolysis and down-regulates the expression of fatty acid transport protein (FATP) and fatty acid translocase (FAT) (X. Chen et al., 2009).

Another study highlighted that pro-inflammatory cytokines such as TNF, IL-1, and IL-6 exert their effect directly on the hepatocytes and suppress transcriptional activity of PPAR and liver $X$ receptor (LXR) by decreasing expression of nuclear hormone receptors: Retinoid $X$ receptor alpha (RXRa), PPARa, PPARy, liver $X$ receptor alpha (LXRa), and coactivators PPARgamma coactivator 1alpha (PGC-1a), PGC-1 $\beta$, and steroid receptor coactivator 1 (SRC-1). These factors play major role in the regulation of the expression of proteins involved in lipid and lipoprotein metabolism, and thus their suppression contributes to the alterations in hepatic lipid metabolism that occurs during inflammation (Kim et al., 2007). Recently, Stienstra et al. (2010) have demonstrated important impact of Kupffer cells on the development of liver steatosis. Interestingly, Kupffer cells have been shown to promote hepatic triglyceride storage via IL-1 $\beta$-dependent inhibition of PPARa expression and activity leading to decreased expression of PPARa target genes involved in mitochondrial and peroxisomal fatty acid oxidation. These findings point toward cross-talk between Kupffer cells and hepatocytes that may be implicated in the pathogenesis of fatty liver disease due to chronic inflammation (Stienstra et al., 2010). With regard to these findings, we observed elevated concentrations of liver triglycerides concomitantly with increased mRNA expression of IL-1 $\beta$ in the liver of cachectic rats with adjuvant arthritis that indicate impaired lipid metabolism caused by inflammation. Although these alterations were not associated with decreased insulin sensitivity (estimated by homeostatic model assessment (HOMA) index) (Stofkova et al., 2010), our other study showed down-regulation of insulindependent glucose transporter GLUT4 in adipocyte membranes of arthritic rats (Jurcovicova et al., 2010). At this point it is important to note that chronic treatment with IL-1 $\beta$ slightly decreases the expression of GLUT4 and inhibits its translocation to the adipocyte plasma membrane in response to insulin. This inhibitory effect is due to a decreased amount of IRS-1 expression in adipocytes (Jager et al., 2007). Similarly, IL-6 and TNF-a exert long term inhibitory effects on the gene transcription of IRS-1, GLUT4, and PPARY in 3T3-L1 adipocytes (Rotter et al., 2003).

In addition to disturbances in lipid homeostasis, pro-inflammatory cytokines have also been reported to affect glucose metabolism. In several studies, chronic elevation in TNF-a, IL-1 $\beta$, or IL-6 levels as well as acute exposure to LPS were associated with reduced blood glucose concentrations without affecting insulin secretion (Metzger et al., 1997a, 1997b, 2004; Grempler et al., 2004; del Rey et al., 2006; Raetzsch et al., 2009). Insulin independent cytokine-induced decrease in circulating glucose levels was accompanied by reduced expression and/or activity of gluconeogenic enzyme glucose-6-phosphatase (Metzger et al., 1997a, 1997b, 2004; Grempler et al., 2004), down-regulation of the mRNA level for GLUT2, the major glucose transporter of the liver, enhanced 2-deoxy-glucose uptake by peripheral tissues (Metzger et al., 2004), or decreased liver glycogen content (Metzger et al., 1997b). 
Notably, increased IL-1 $\beta$ levels are able to block D-fructose intestinal uptake through inhibition of GLUT5 intrinsic activity by induction of NO signaling pathways. This effect of IL-1 $\beta$ importantly contributes to hypoglycemia (Garcia-Barrios et al., 2010). Nevertheless, besides the above mentioned peripheral mechanisms, hypoglycemic effect of IL-1 $\beta$ also involves mechanisms integrated in the brain since blockade of IL-1 receptors in the brain partially counteracted IL-1-induced hypoglycemia (del Rey et al., 2006).

Another cytokine that controls carbohydrate metabolism is macrophage migration inhibitory factor (MIF). Addition of MIF to differentiated L6 rat myotubes increased synthesis of fructose 2,6-bisphosphate (F2,6BP), a positive allosteric regulator of glycolysis. The same effect, followed by decreased serum glucose level, was found when TNF-a was administered to mice. However, pretreatment with a neutralizing anti-MIF mAb completely inhibited this effect. Moreover, anti-MIF also prevented hypoglycemia and increased muscle F2,6BP levels in TNF-a-knockout mice after LPS administration (Benigni et al., 2000).

The cytokine-induced decline in plasma glucose levels may be an important initiating event that promotes the hydrolysis of triglycerides in adipose tissue and the proteolysis in muscles to provide gluconeogenic precursors. These results suggest that pro-inflammatory cytokines may cause metabolic disturbances through several direct and/or indirect mechanisms.

\section{Cytokines and cachexia-related chronic diseases}

Cachexia syndrome is characterized by an excessive expression of pro-inflammatory cytokines which is proposed as a consequence of an imbalance between apoptosis (proinflammatory) and wound healing (anti-inflammatory) properties of immune cell responses (Khatami, 2008, 2009, 2011). This disturbance and the relationship between proinflammatory cytokines, wasting, and mortality is a common denominator of multiple cachexia-related chronic diseases. Cachectic patients with chronic heart failure have markedly increased plasma levels of TNF- $\alpha$, IL-6 and IL-1 compared to non-cachectic patients with chronic heart failure having near-normal levels (Filippatos et al., 2005). Indeed, circulating levels of IL-6 and TNF- $\alpha$ increase in patients as their functional heart failure classification deteriorates (Torre-Amione et al., 1996). Elevated levels of pro-inflammatory cytokines IL-1, IL-2, IL-6, IFN- $\gamma$, and TNF- $\alpha$ have also been observed in HIV patients with severe weight loss (Gelato et al., 2007). In patients with chronic kidney disease, increased serum CRP level positively correlating with IL-6 is associated with a higher cardiovascular disease risk. Moreover, particularly IL-6, whose level is dependent on stimulation of TNF- $\mathrm{a}$ and IL-1, predicts mortality in patients with end-stage renal disease (Cheung et al., 2010). In patients with rheumatoid arthritis, the overproduction of TNF- $\alpha$ and IL-1 $\beta$ is associated with hypermetabolism and reduced body cell mass, and serum concentrations of these cytokines as well as IL-6, IL-15, IL-18, and IL-12 correlate strongly with disease severity (Roubenoff et al., 1994; Petrovic-Rackov \& Pejnovic, 2006; de Paz et al., 2010). Patients with COPD also exhibit an increase in resting energy expenditure and a decrease in free-fat mass, and these patients have markedly increased acute phase reactant proteins and inflammatory factors (IL-8, soluble TNF receptors: sTNF-R55 and sTNF-R75) in their serum (Schols et al., 1996). Furthermore, TNF- $\alpha$, IL-1 $\beta$ and IL-6 blood levels are significantly elevated in patients with COPD compared to those in healthy subjects, and that may contribute to a shift toward catabolism and development of cachexia in these patients (Debigare et al., 2003; von Heahling et al., 2009; Singh et al., 2010). The pathophysiology of cancer cachexia is associated with number of pro-inflammatory, pro-cachectic and apoptotic factors (e.g. 


\begin{tabular}{|c|c|c|}
\hline Cytokine & Proposed functions in the pathogenesis of cachexia & Chronic disease \\
\hline TNF- $a$ & $\begin{array}{l}\text { Anorectic effect ( } \uparrow \text { synthesis of IL-1 } \mathrm{A} / \beta \text { in the brain); } \\
\uparrow \text { muscle protein degradation (activation of ubiquitin- } \\
\text { proteasome system and muscle-specific E3 ubiquitin ligases } \\
\text { (MuRF-1 and atrogin- } 1 \text { /MAFbx) via NF-KB, FOXO1, } \\
\text { MAPKs or PI3-K/Akt pathways); } \downarrow \text { muscle protein } \\
\text { synthesis (negatively interferes with mRNA translation, } \\
\text { and inhibits expression and effect of IGF-I); } \downarrow \text { myogenic } \\
\text { differentiation (MyoD destabilization in a NF-kB- } \\
\text { dependent manner); } \uparrow \text { apoptosis of differentiated myotubes; } \\
\uparrow \text { insulin resistance (phosphorylation of IRS at inhibitory Ser } \\
\text { sites); } \uparrow \text { triglyceride and cholesterol plasma levels; } \\
\text { hypoglycemic effect (insulin independent) }\end{array}$ & $\begin{array}{l}\text { Cancer } \\
\text { COPD } \\
\text { HIV/AIDS } \\
\text { Heart failure } \\
\text { Renal failure } \\
\text { Rheumatoid } \\
\text { arthritis } \\
\text { Sepsis }\end{array}$ \\
\hline $\begin{array}{l}\text { IL-1a } \\
\text { and/or } \\
\text { IL-1 } \beta\end{array}$ & $\begin{array}{l}\text { Anorectic effect (central melanocortin system activation); } \\
\downarrow \text { gastric emptying; } \uparrow \text { muscle protein degradation } \\
\text { ( } \uparrow \text { expression of atrogin- } 1 \text { /MAFbx and MuRF- } 1 \text { via p38 } \\
\text { MAPK and NF-kB signaling, } \uparrow T N F-\alpha \text { expression in skeletal } \\
\text { and cardiac muscle); } \uparrow \text { insulin resistance (phosphorylation } \\
\text { of IRS at inhibitory Ser sites, } \downarrow \text { IRS- } 1 \text { expression in } \\
\text { adipocytes, } \downarrow \text { GLUT4 expression and translocation to the } \\
\text { plasma membrane, } \downarrow \text { liver PPARa expression and activity); } \\
\uparrow \text { triglyceride and cholesterol plasma levels; hypoglycemic } \\
\text { effect (insulin independent) }\end{array}$ & $\begin{array}{l}\text { Cancer } \\
\text { COPD } \\
\text { HIV/AIDS } \\
\text { Heart failure } \\
\text { Renal failure } \\
\text { Rheumatoid } \\
\text { arthritis } \\
\text { Sepsis }\end{array}$ \\
\hline IL-6 & $\begin{array}{l}\text { Anorectic effect (only after central administration or co- } \\
\text { administration with IL-1 } \beta \text { ); predominantly } \uparrow \text { adipose tissue } \\
\text { loss ( } \uparrow \text { lipolysis) than skeletal muscle loss; } \uparrow \text { insulin } \\
\text { resistance (phosphorylation of IRS at inhibitory Ser sites } \\
\text { and } \uparrow S O C S-3 \text { expression in liver, } \downarrow \text { IRS-1, GLUT4 and } \\
\text { PPARY gene expression in adipocytes); } \uparrow \text { triglyceride and } \\
\text { cholesterol plasma levels; hypoglycemic effect (insulin } \\
\text { independent) }\end{array}$ & $\begin{array}{l}\text { Cancer } \\
\text { COPD } \\
\text { HIV/AIDS } \\
\text { Heart failure } \\
\text { Renal failure } \\
\text { Rheumatoid } \\
\text { arthritis } \\
\text { Sepsis }\end{array}$ \\
\hline IFNs & $\begin{array}{l}\text { Anorectic effect (depression of neuronal electrical activity } \\
\text { in the lateral hypothalamus); } \uparrow \text { muscle wasting (synergize } \\
\text { TNF-a effect); } \uparrow \text { insulin resistance (phosphorylation of IRS at } \\
\text { inhibitory Ser sites) }\end{array}$ & $\begin{array}{l}\text { Cancer } \\
\text { HIV/AIDS }\end{array}$ \\
\hline CNTF & $\begin{array}{l}\text { Long-term anorectic effect (suppression of NPYergic } \\
\text { signaling in the hypothalamus, gp130-mediated activation } \\
\text { of POMC neurons) }\end{array}$ & Cancer \\
\hline LIF & $\begin{array}{l}\text { Anorectic effect (gp130-mediated activation of POMC } \\
\text { neurons in ARC); promotes inhibition of myoblast } \\
\text { differentiation mediated by TNF-a; } \downarrow \text { contractile functions of } \\
\text { cardiomyocytes; } \uparrow \text { insulin resistance in cardiomyocytes }\end{array}$ & $\begin{array}{l}\text { Cancer } \\
\text { Heart failure }\end{array}$ \\
\hline
\end{tabular}

Table 1. Selected key cytokines involved in cachexia-related chronic diseases 
TNF-a, IL-1, IL-6, IFN- $\gamma$, LIF, and CNTF) that can be produced not only by the host's immune response but also by tumor cells. Prolonged excessive production of these mediators is causally related with the decreased quality of life and survival time of the patients (Argiles et al., 2005). Inflammatory cytokines such as TNF- $\alpha$, IL-1, IL-6, and INF- $\gamma$ are also implicated in anorexia, weight loss and whole body inflammation in patients with sepsis. However, sepsis shows a biphasic immunological pattern characterized by an early hyperinflammatory phase and a late anti-inflammatory phase which may lead to immunodeficiency. Therefore clinical trials aimed at down-regulating inflammatory mediators were not successful consistently (Kox et al., 2000). The potential contribution of key proinflammatory cytokines to anorexia-cachexia syndrome in chronic diseases shows Table 1.

\section{Conclusion}

Our understanding how inflammatory cytokines disrupt physiological mechanisms regulating food intake, muscle homeostasis and insulin sensitivity, and how these disruptions affect disease severity and quality of life in patients with cachexia enhanced majorly over the past decade. At the present time, sufficient evidence is available to indicate that cytokines are able to: (1) Enter the brain and interact with neuronal circuits involved in the control of energy balance, resulting in anorexia; (2) Accumulate in the skeletal or cardiac muscle and accelerate muscle catabolism (the effect on cardiac muscle contributes to the increased risk of heart failure); (3) Interact with insulin signaling (directly or through altered lipid metabolism), causing insulin resistance and promoting muscle wasting; and (4) Generate dyslipidemia, the most important risk factor for atherosclerosis. Currently, despite their key role in the pathogenesis of cachexia, anti-cytokine strategies for the treatment of cachexia brought controversial results. Regarding a fact that cytokines act in a complex harmony of interactions, rather than as isolated triggers of their own, blocking a single cytokine cannot prevent cachexia. Therefore, there is a need for research focusing on pharmacological treatment not against a single cytokine but rather against multiple cytokines or transcriptional factors common for a set of crucial cytokines.

\section{Acknowledgements}

The review was supported by Grant MSM 0021620816 from the Czech Ministry of Education.

\section{References}

Acharyya, S.; Ladner, K.J.; Nelsen, L.L.; Damrauer, J.; Reiser, P.J.; Swoap, S. \& Guttridge, D.C. (2004). Cancer cachexia is regulated by selective targeting of skeletal muscle gene products. The Journal of Clinical Investigation, Vol.114, No.3, (August 2004), pp. 370-8, ISSN 0021-9738

Alter, J.; Rozentzweig, D. \& Bengal, E. (2008). Inhibition of myoblast differentiation by tumor necrosis factor alpha is mediated by c-Jun N-terminal kinase 1 and leukemia inhibitory factor. The Journal of Biological Chemistry, Vol.283, No.34, (August 2008), pp. 23224-34, ISSN 0021-9258

Argiles, J.M.; Busquets, S. \& Lopez-Soriano, F.J. (2005). The pivotal role of cytokines in muscle wasting during cancer. The International Journal of Biochemistry $\mathcal{E}$ Cell Biology, Vol.37, No.10, (October 2005), pp. 2036-46, ISSN 1357-2725 
Argiles, J.M.; Lopez-Soriano, F.J. \& Busquets, S. (2009). Therapeutic potential of interleukin15: a myokine involved in muscle wasting and adiposity. Drug Discovery Today, Vol.14, No.3-4, (February 2009), pp. 208-13, ISSN1359-644

Asp, M.L.; Tian, M.; Wendel, A.A. \& Belury, M.A. (2010). Evidence for the contribution of insulin resistance to the development of cachexia in tumor-bearing mice. International Journal of Cancer. Journal International Du Cancer, Vol.126, No.3, (February 2010), pp. 756-63, ISSN 0020-7136

Authier, F.J.; Chazaud, B.; Mhiri, C.; Eliezer-Vanerot, M.C.; Poron, F.; Barlovatz-Meimon, G. \& Gherardi, R.K. (1997). Interleukin-1 expression in normal motor endplates and muscle fibers showing neurogenic changes. Acta Neuropathologica, Vol.94, No.3, (September 1997), pp. 272-9, ISSN 0001-6322

Benigni, F.; Atsumi, T.; Calandra, T.; Metz, C.; Echtenacher, B.; Peng, T. \& Bucala, R. (2000). The proinflammatory mediator macrophage migration inhibitory factor induces glucose catabolism in muscle. The Journal of Clinical Investigation, Vol.106, No.10, (November 2000), pp. 1291-300, ISSN0021-9738

Boden, G. (2001). Free fatty acids-the link between obesity and insulin resistance. Endocrine Practice: Official Journal of the American College of Endocrinology and the American Association of Clinical Endocrinologists, Vol.7, No.1, (January - February 2001), pp. 4451, ISSN 1530-891X

Buchanan, J.B. \& Johnson, R.W. (2007). Regulation of food intake by inflammatory cytokines in brain. Neuroendocrinology, Vol. 86, No.3, pp. 183-190, ISSN 0028-3835

Burks, T.N. \& Cohn, R.D. (2011). Role of TGF- $\beta$ signaling in inherited and acquired myopathies. Skeletal Muscle, Vol.1, No.19, (May 2011), pp. 1-13, ISSN 2044-5040

Carbo, N.; Lopez-Soriano, J.; Costelli, P.; Busquets, S.; Alvarez, B.; Baccino, F.M.; Quinn, L.S.; Lopez-Soriano, F.J. \& Argiles, J.M. Interleukin-15 antagonizes muscle protein waste in tumour-bearing rats. British Journal of Cancer, Vol.83, No.4, (August 2000), pp. 526-31, ISSN 0007-0920

Carson, J.A. \& Baltgalvis, K.A. (2010). Interleukin 6 as a key regulator of muscle mass during cachexia. Exercise and Sport Sciences Reviews, Vol.38, No.4, (October 2010), pp. 16876, ISSN 0091-6331

Chang, L.; Zhao, J.; Yang, J.; Zhang, Z.; Du, J. \& Tang, C. (2003). Therapeutic effects of ghrelin on endotoxic shock in rats. European Journal of Pharmacology, Vol.473, No.23, (July 2003), pp. 171-6, ISSN 0014-2999

Chen, X.; Xun, K.; Chen, L. \& Wang, Y. (2009). TNF-alpha, a potent lipid metabolism regulator, Cell Biochemistry and Function, Vol.27, No.7, pp. 407-416, ISSN 0263-6484

Chen, Z.J. (2005). Ubiquitin signalling in the NF-kappaB pathway. Nature Cell Biology, Vol.7, No.8, (August 2005), pp. 758-65, ISSN 1097-6256

Cheng, M.; Nguyen, M.H.; Fantuzzi, G. \& Koh, T.J. (2008). Endogenous interferon-gamma is required for efficient skeletal muscle regeneration. American Journal of Physiology. Cell Physiology, Vol.294, No.5, (May 2008), pp.1183-91, ISSN 0363-6143

Cheung, W.W.; Paik, K.H. \& Mak, R.H. (2010). Inflammation and cachexia in chronic kidney disease. Pediatric Nephrology : Journal of the International Pediatric Nephrology Association, Vol.25, No.4, (April 2010), pp. 711-24, ISSN 0931-041X

Chorny, A.; Anderson, P.; Gonzalez-Rey, E. \& Delgado, M. (2008). Ghrelin protects against experimental sepsis by inhibiting high-mobility group box 1 release and by killing bacteria. The Journal of Immunology, Vol.180, No.12, (June 2008), pp. 8369-77, ISSN 0022-1767 
Combaret, L.; Tilignac, T.; Claustre, A.; Voisin, L.; Taillandier, D.; Obled, C.; Tanaka, K. \& Attaix, D. Torbafylline (2002). (HWA 448) inhibits enhanced skeletal muscle ubiquitin-proteasome-dependent proteolysis in cancer and septic rats. Biochemical Journal, Vol.361, No.Pt 2, (January 2002), pp. 185-92, ISSN 0264-6021

Costelli, P.; Carbo, N.; Tessitore, L.; Bagby, G.J.; Lopez-Soriano, F.J.; Argilés, J.M. \& Baccino, F.M. (1993). Tumor necrosis factor-alpha mediates changes in tissue protein turnover in a rat cancer cachexia model. The Journal of Clinical Investigation, Vol.92, No.6, (December 1993), pp. 2783-9, ISSN 0021-9738

Crossland, H.; Constantin-Teodosiu, D.; Gardiner, S.M.; Constantin, D. \& Greenhaff, P.L. (2008). A potential role for Akt/FOXO signalling in both protein loss and the impairment of muscle carbohydrate oxidation during sepsis in rodent skeletal muscle. The Journal of Physiology, Vol.586, No.Pt 22, (November 2008), pp. 5589-600, ISSN 0022-3751

de Paz, B.; Alperi-Lopez, M.; Ballina-Garcia, F.J.; Prado, C.; Gutierrez, C. \& Suarez, A. (2010). Cytokines and regulatory $\mathrm{T}$ cells in rheumatoid arthritis and their relationship with response to corticosteroids. The Journal of Rheumatology, Vol.37, No.12, (December 2010), pp. 2502-10, ISSN 0315-162X

Debigare, R.; Marquis, K.; Cote, C.H.; Tremblay, R.R.; Michaud, A.; LeBlanc, P. \& Maltais, F. (2003). Catabolic/anabolic balance and muscle wasting in patients with COPD. Chest, Vol.124, No.1, (July 2003), pp. 83-9, ISSN 0012-3692

DeBoer, M.D. \& Marks, D.L. (2006). Cachexia: lessons from melanocortin antagonism. Trends in Endocrinology and Metabolism, Vol.17, No.5, (July 2006), pp. 199-204, ISSN 10432760

Deboer, M.D.; Zhu, X.; Levasseur, P.R.; Inui, A.; Hu, Z.; Han, G.; Mitch, W.E.; Taylor, J.E.; Halem, H.A.; Dong, J.Z.; Datta, R.; Culler, M.D. \& Marks, D.L. (2008). Ghrelin treatment of chronic kidney disease: improvements in lean body mass and cytokine profile. Endocrinology, Vol.149, No.2, (February 2008), pp. 827-35, ISSN 0013-7227

del Rey, A.; Randolf, A.; Wildmann, J.; Besedovsky, H.O. \& Jessop, D.S. (2009). Re-exposure to endotoxin induces differential cytokine gene expression in the rat hypothalamus and spleen. Brain, Behavior, and Immunity, Vol.23, No.6, (August 2009), pp. 776-83, ISSN 0889-1591

del Rey, A.; Roggero, E.; Randolf, A.; Mahuad, C.; McCann, S.; Rettori, V. \& Besedovsky, H.O. (2006). IL-1 resets glucose homeostasis at central levels. Proceedings of the National Academy of Sciences of the United States of America, Vol.103, No.43, (October 2006), pp. 16039-44, ISSN 0027-8424

Delahanty D.L. \& Cremeans-Smith J.K. (2002). Behavioral Neuroimmunology, In: Encyclopedia of the Human Brain, V. S. Ramachandran (Ed.), 393-404, Academic Press, ISBN 978-0-12-227210-3, San Diego, California, USA

Dinarello, C.A. (1996) Biologic basis for interleukin-1 in disease. Blood, Vol.87, No.6, (March 1996), pp. 2095-147, ISSN 0006-4971.

Dixit, V.D.; Schaffer, E.M.; Pyle, R.S.; Collins, G.D.; Sakthivel, S.K.; Palaniappan, R.; Lillard, J.W. Jr. \& Taub, D.D. (2004). Ghrelin inhibits leptin- and activation-induced proinflammatory cytokine expression by human monocytes and T cells. The Journal of Clinical Investigation, Vol.114, No.1, (July 2004), pp. 57-66, ISSN 0021-9738.

Doehner, W.; Gathercole, D.; Cicoira, M.; Krack, A.; Coats, A.J.; Camici, P.G. \& Anker, S.D. (2008). Reduced glucose transporter GLUT4 in skeletal muscle predicts insulin resistance in non-diabetic chronic heart failure patients independently of body 
composition. International Journal of Cardiology, Vol.138, No.1, (January 2010), pp. 19-24, ISSN 0167-5273

Donath, M.Y.; Ehses, J.A.; Maedler, K.; Schumann, D.M.; Ellingsgaard, H.; Eppler, E. \& Reinecke, M. (2005). Mechanisms of beta-cell death in type 2 diabetes. Diabetes, Vol.54, No.2, (December 2005), pp. S108-13, ISSN 0012-1797

Elander, L.; Engstrom, L.; Hallbeck, M. \& Blomqvist, A. (2007). IL-1beta and LPS induce anorexia by distinct mechanisms differentially dependent on microsomal prostaglandin E synthase-1. American Journal of Physiology. Regulatory, Integrative and Comparative Physiology, Vol.292, No.1, (January 2007), pp. R258-67, ISSN 03636119

El-Haj, T.; Poole, S.; Farthing, M.J. \& Ballinger, A.B. (2002). Anorexia in a rat model of colitis: interaction of interleukin-1 and hypothalamic serotonin. Brain Research, Vol.927, No.1, (February 2002), pp. 1-7, ISSN 0006-8993

Elkan, A.C.; Hakansson, N.; Frostegard, J.; Cederholm, T. \& Hafstrom, I. (2009). Rheumatoid cachexia is associated with dyslipidemia and low levels of atheroprotective natural antibodies against phosphorylcholine but not with dietary fat in patients with rheumatoid arthritis: a cross-sectional study. Arthritis Research \& Therapy, Vol.11, No.2, pp. R37, ISSN 1478-6354

Evans, W.J.; Morley, J.E.; Argiles, J.; Bales, C.; Baracos, V.; Guttridge, D.; Jatoi, A.; KalantarZadeh, K.; Lochs, H.; Mantovani, G.; Marks, D.; Mitch, W.E.; Muscaritoli, M.; Najand, A.; Ponikowski, P.; Rossi Fanelli, F.; Schambelan, M.; Schols, A.; Schuster, M.; Thomas, D.; Wolfe, R. \& Anker, S.D. (2008). Cachexia: a new definition. Clinical nutrition (Edinburgh, Scotland) Vol.27, No.6, (December 2008), pp. 793-9, ISSN 02615614

Faggioni, R.; Fuller, J.; Moser, A.; Feingold, K.R. \& Grunfeld, C. (1997). LPS-induced anorexia in leptin-deficient $(\mathrm{ob} / \mathrm{ob})$ and leptin receptor-deficient $(\mathrm{db} / \mathrm{db})$ mice. The American Journal of Physiology, Vol.273, No.1 Pt 2, (July 1997), pp. R181-6, ISSN 00029513

Fan, W.; Boston, B.A.; Kesterson, R.A.; Hruby, V.J. \& Cone, R.D. (1997). Role of melanocortinergic neurons in feeding and the agouti obesity syndrome. Nature, Vol.385, No.6612, (January 1997), pp. 165-8, ISSN 0028-0836

Feingold, K.R.; Marshall, M.; Gulli, R.; Moser, A.H. \& Grunfeld, C. (1994). Arteriosclerosis and Thrombosis: A Journal of Vascular Biology / American Heart Association, Vol.14, No.11, (November 1994), pp. 1866-72, ISSN 1049-8834

Fernandez-Celemin, L.; Pasko, N.; Blomart, V. \& Thissen, J.P. (2002). Inhibition of muscle insulin-like growth factor I expression by tumor necrosis factor-alpha. American journal of physiology. Endocrinology and metabolism, Vol.283, No.6, (December 2002), pp. E1279-90, ISSN 0193-1849

Figueras, M.; Busquets, S.; Carbo, N.; Barreiro, E.; Almendro, V.; Argiles, J.M. \& LopezSoriano, F.J. (2004). Interleukin-15 is able to suppress the increased DNA fragmentation associated with muscle wasting in tumour-bearing rats. FEBS Letters, Vol.569, No.1-3, (July 2004), pp. 201-6, ISSN 0014-5793

Filippatos, G.S.; Anker, S.D. \& Kremastinos, D.T. (2005) Pathophysiology of peripheral muscle wasting in cardiac cachexia. Current Opinion in Clinical Nutrition and Metabolic Care, Vol.8, No.3, (May 2005), pp. 249-54, ISSN 1363-1950

Florholmen, G.; Aas, V., Rustan, A.C.; Lunde, P.K.; Straumann, N.; Eid, H.; Odegaard, A.; Dishington, H.; Andersson, K.B. \& Christensen, G. (2004). Leukemia inhibitory 
factor reduces contractile function and induces alterations in energy metabolism in isolated cardiomyocytes. Journal of Molecular and Cellular Cardiology, Vol.37, No.6, (December 2004), pp. 1183-93, ISSN 0022-2828

Florholmen, G.; Thoresen, G.H.; Rustan, A.C.; Jensen, J.; Christensen, G. \& Aas, V. (2006). Leukaemia inhibitory factor stimulates glucose transport in isolated cardiomyocytes and induces insulin resistance after chronic exposure. Diabetologia, Vol.49, No.4, (April 2006), pp. 724-31, ISSN 0012-186X

Fraser, D.A.; Thoen, J.; Reseland, J.E.; Forre, O. \& Kjeldsen-Kragh, J. (1999). Decreased CD4+ lymphocyte activation and increased interleukin-4 production in peripheral blood of rheumatoid arthritis patients after acute starvation. Clinical Rheumatology, Vol.18, No.5, pp. 394-401, ISSN 0770-3198

Garcia, M.C.; Wernstedt, I.; Berndtsson, A.; Enge, M.; Bell, M.; Hultgren, O.; Horn, M.; Ahrén, B.; Enerback, S.; Ohlsson, C.; Wallenius, V. \& Jansson, J.O. (2006). Matureonset obesity in interleukin-1 receptor I knockout mice. Diabetes, Vol.55, No.5, (May 2006), pp. 1205-13, ISSN 0012-1797

Garcia-Barrios, A.; Guillén, N.; Gascon, S.; Osada, J.; Vazquez, C.M.; Miguel-Carrasco, J.L. \& Rodriguez-Yoldi, M.J. (2010). Nitric oxide involved in the IL-1 $\beta$-induced inhibition of fructose intestinal transport. Journal of Cellular Biochemistry, Vol.111, No.5, (December 2010), pp. 1321-9, ISSN 0730-2312

Garcia-Martinez, C.; Agell, N.; Llovera, M.; Lopez-Soriano, F.J. \& Argiles, J.M. (1993). Tumour necrosis factor-alpha increases the ubiquitinization of rat skeletal muscle proteins. FEBS Letters, Vol.323, No.3, (June 1993), pp. 211-4, ISSN 0014-5793

Garcia-Martinez, C.; Llovera, M.; Agell, N.; Lopez-Soriano, F.J. \& Argiles, J.M. (1994). Ubiquitin gene expression in skeletal muscle is increased by tumour necrosis factor-alpha. Biochemical and Biophysical Research Communications, Vol.201, No.2, (June 1994), pp. 682-6, ISSN 0006-291X

Garcia-Martinez, C.; Llovera, M.; Agell, N.; Lopez-Soriano, F.J. \& Argiles, J.M. (1995). Ubiquitin gene expression in skeletal muscle is increased during sepsis: involvement of TNF-alpha but not IL-1. Biochemical and Biophysical Research Communications, Vol.217, No.3, (December 1995), pp. 839-44, ISSN 0006-291X

Gautron, L.; Mingam, R.; Moranis, A.; Combe, C. \& Laye, S. (2005). Influence of feeding status on neuronal activity in the hypothalamus during lipopolysaccharideinduced anorexia in rats. Neuroscience, Vol.134, No.3, pp. 933-46, ISSN 0306-4522

Gelato, M.; McNurlan, M. \& Freedland, E. (2007). Role of recombinant human growth hormone in HIV-associated wasting and cachexia: pathophysiology and rationale for treatment. Clinical Therapeutics, Vol.29, No.11, (November 2007), pp. 2269-88, ISSN 0149-2918

Glass, D. \& Roubenoff, R. (2010). Recent advances in the biology and therapy of muscle wasting. Annals of the New York Academy of Sciences, Vol.1211, No., (November 2010), pp. 25-36, ISSN 0077-8923

Gonzalez, P.V.; Cragnolini, A.B.; Schioth, H.B. \& Scimonelli, T.N. (2006). Interleukin-1betainduced anorexia is reversed by ghrelin. Peptides, Vol.27, No.12, (December 2006), pp. 3220-5, ISSN 0196-9781

Gonzalez-Rey, E.; Chorny, A. \& Delgado, M. (2006). Therapeutic action of ghrelin in a mouse model of colitis. Gastroenterology, Vol.130, No.6, (May 2006), pp. 1707-20, ISSN 0016-5085 
Goodman, M.N. (1994). Interleukin-6 induces skeletal muscle protein breakdown in rats. Proceedings of the Society for Experimental Biology and Medicine, Vol.205, No.2, (February 1994), pp. 182-5, ISSN 0037-9727

Granado, M.; Priego, T.; Martin, A.I.; Villanua, M.A. \& Lopez-Calderon, A. (2005a). Antiinflammatory effect of the ghrelin agonist growth hormone-releasing peptide-2 (GHRP-2) in arthritic rats. American Journal of Physiology. Endocrinology and Metabolism, Vol.288, No.3, (March 2005), pp. E486-92, ISSN 0193-1849

Granado, M.; Priego, T.; Martin, A.I.; Villanua, M.A. \& Lopez-Calderon, A. Ghrelin (2005b). receptor agonist GHRP-2 prevents arthritis-induced increase in E3 ubiquitinligating enzymes MuRF1 and MAFbx gene expression in skeletal muscle. American Journal of Physiology. Endocrinology and Metabolism, Vol.289, No.6, (December 2005), pp. E1007-14, ISSN 0193-1849

Grempler, R.; Kienitz, A.; Werner, T.; Meyer, M.; Barthel, A.; Ailett, F.; Sutherland, C.; Walther, R. \& Schmoll, D. (2004). Tumour necrosis factor alpha decreases glucose-6phosphatase gene expression by activation of nuclear factor kappaB. Biochemical Journal, Vol.382, No.Pt 2, (September 2004), pp. 471-9, ISSN 0264-6021

Grossberg, A.J.; Scarlett, J.M. \& Marks, D.L. (2010). Hypothalamic mechanisms in cachexia. Physiology \& Behavior, Vol.100, No.5, (July 2010), pp. 478-89, ISSN 0031-9384

Grunfeld, C. \& Feingold, K.R. (1992). The role of the cytokines, interferon alpha and tumor necrosis factor in the hypertriglyceridemia and wasting of AIDs. Journal of Nutrition, Vol.122, No.3, (March 1992), pp. 749-53, ISSN 0022-3166

Grzelkowska-Kowalczyk, K. \& Wieteska-Skrzeczyńska, W. (2009). Treatment with TNFalpha and IFN-gamma alters the activation of SER/THR protein kinases and the metabolic response to IGF-I in mouse c2c12 myogenic cells. Cellular $\mathcal{E}$ Molecular Biology Letters, Vol.15, No.1, pp. 13-31, ISSN 1425-8153

Gurevitch, D.; Boura-Halfon, S.; Isaac, R.; Shahaf, G.; Alberstein, M.; Ronen, D.; Lewis, E.C. \& Zick, Y. (2010). Elimination of negative feedback control mechanisms along the insulin signaling pathway improves beta-cell function under stress. Diabetes, Vol.59, No.9, (September 2010), pp. 2188-97, ISSN 0012-1797

Guttridge, D.C.; Mayo, M.W.; Madrid, L.V.; Wang, C.Y. \& Baldwin, A.S. Jr. (2000). NFkappaB-induced loss of MyoD messenger RNA: possible role in muscle decay and cachexia. Science, Vol.289, No.5488, (September 2000), pp. 2363-6, ISSN 0036-8075

Harcourt, L.J.; Holmes, A.G.; Gregorevic, P.; Schertzer, J.D.; Stupka, N.; Plant, D.R. \& Lynch, G.S. (2005). Interleukin-15 administration improves diaphragm muscle pathology and function in dystrophic mdx mice. The American Journal of Pathology, Vol.166, No.4, (April 2005), pp. 1113-41, ISSN 0002-9440

Hashimoto, H.; Azuma, Y.; Kawasaki, M.; Fujihara, H.; Onuma, E.; Yamada-Okabe, H.; Takuwa, Y.; Ogata, E. \& Ueta, Y. (2007). Parathyroid hormone-related protein induces cachectic syndromes without directly modulating the expression of hypothalamic feeding-regulating peptides. Clinical Cancer Research, Vol.13, No.1, (January 2007), pp. 292-8, ISSN 1078-0432

Hehlgans, T. \& Pfeffer, K. (2005). The intriguing biology of the tumour necrosis factor/tumour necrosis factor receptor superfamily: players, rules and the games. Immunology, Vol.115, No.1, (May 2005), pp. 1-20, ISSN 1365-2567

Heisler, L.K.; Jobst, E.E.; Sutton, G.M.; Zhou, L.; Borok, E.; Thornton-Jones, Z.; Liu, H.Y.; Zigman, J.M.; Balthasar, N.; Kishi, T.; Lee, C.E.; Aschkenasi, C.J.; Zhang, C.Y.; Yu, J.; Boss, O.; Mountjoy, K.G.; Clifton, P.G.; Lowell, B.B.; Friedman, J.M.; Horvath, T.; 
Butler, A.A.; Elmquist, J.K. \& Cowley, M.A. (2006). Serotonin reciprocally regulates melanocortin neurons to modulate food intake. Neuron, Vol.51, No.2, (July 2006), pp. 239-49, ISSN 0896-6273

Hotamisligil, G.S. (2003). Inflammatory pathways and insulin action. International Journal of Obesity and Related Metabolic Disorders: Journal of the International Association for the Study of Obesity, Vol.27, No.3, (December 2003), pp. S53-5, ISSN 0307-0565

Hunt, L.C.; Upadhyay, A.; Jazayeri, J.A.; Tudor, E.M. \& White, J.D. (2011). Caspase-3, myogenic transcription factors and cell cycle inhibitors are regulated by leukemia inhibitory factor to mediate inhibition of myogenic differentiation. Skeletal Muscle, Vol.1, No.17, (April 2011), pp. 1-13, ISSN 2044-5040

Iwase, S.; Murakami, T.; Saito, Y. \& Nakagawa, K. (2004). Steep elevation of blood interleukin-6 (IL-6) associated only with late stages of cachexia in cancer patients. European Cytokine Network, Vol.15, No.4, (October - December 2004), pp. 312-6, ISSN 1148-5493

Jager, J.; Gremeaux, T.; Cormont, M.; Le Marchand-Brustel, Y. \& Tanti, J.F. (2007). Interleukin-1beta-induced insulin resistance in adipocytes through downregulation of insulin receptor substrate-1 expression. Endocrinology, Vol.148, No.1, (January 2007), pp. 241-51, ISSN 0013-7227

Janoschek, R.; Plum, L.; Koch, L.; Munzberg, H.; Diano, S.; Shanabrough, M.; Muller, W.; Horvath, T.L. \& Bruning, J.C. (2006). gp130 signaling in proopiomelanocortin neurons mediates the acute anorectic response to centrally applied ciliary neurotrophic factor. Proceedings of the National Academy of Sciences of the United States of America, Vol.103, No.28, (July 2006), pp. 10707-12, ISSN 0027-8424

Jurcovicova, J.; Stancikova, M.; Svik, K.; Ondrejickova, O.; Krsova, D.; Seres, J. \& Rokyta, R. (2001). Stress of chronic food restriction attenuates the development of adjuvant arthritis in male Long Evans rats. Clinical and Experimental Rheumatology, Vol.19, No.4, (July - August 2001), ISSN 1593-098X

Jurcovicova, J.; Stofkova, A.; Skurlova, M.; Baculikova, M.; Zorad, S. \& Stancikova, M. (2010). Alterations in adipocyte glucose transporter GLUT4 and circulating adiponectin and visfatin in rat adjuvant induced arthritis. General Physiology and Biophysics, Vol.29, No.1, (March 2010), pp. 79-84, ISSN 0231-5882

Kent, S.; Kelley, K.W. \& Dantzer, R. (1992). Effects of lipopolysaccharide on food-motivated behavior in the rat are not blocked by an interleukin-1 receptor antagonist. Neuroscience Letters, Vol.145, No.1, (September 1992), pp. 83-6, ISSN 0304-3940

Kent, S.; Rodriguez, F.; Kelley, K.W. \& Dantzer, R. (1994). Reduction in food and water intake induced by microinjection of interleukin-1 beta in the ventromedial hypothalamus of the rat. Physiology \& Behavior, Vol.56, No.5, (November 1994), pp. 1031-6, ISSN 0031-9384

Khatami, M. (2008). 'Yin and Yang' in inflammation: duality in innate immune cell function and tumorigenesis. Expert Opinion on Biological Therapy, Vol.8, No.10, (October 2008), pp. 1464-72, ISSN 1471-2598

Khatami, M. (2009). Inflammation, aging, and cancer: tumoricidal versus tumorigenesis of immunity: a common denominator mapping chronic diseases. Cell Biochemistry and Biophysics, Vol.55, No.2, pp. 55-79, ISSN 1085-9195

Khatami, M. (2011). Unresolved inflammation: 'immune tsunami' or erosion of integrity in immune-privileged and immune-responsive tissues and acute and chronic 
inflammatory diseases or cancer. Expert Opinion on Biological Therapy, (Jun 2011), Epub ahead of print, ISSN 1471-2598

Kim, M.S.; Sweeney, T.R.; Shigenaga, J.K.; Chui, L.G.; Moser, A.; Grunfeld, C. \& Feingold, K.R. (2007). Tumor necrosis factor and interleukin 1 decrease RXRalpha, PPARalpha, PPARgamma, LXRalpha, and the coactivators SRC-1, PGC-1alpha, and PGC-1beta in liver cells. Metabolism: Clinical and Experimental, Vol.56, No.2, (February 2007), pp. 267-79, ISSN 0026-0495

King, P.J.; Widdowson, P.S.; Doods, H. \& Williams, G. (2000). Effect of cytokines on hypothalamic neuropeptide Y release in vitro. Peptides, Vol.21, No.1, (January 2000), pp. 143-6, ISSN 0196-9781.

Kokoeva, M.V.; Yin, H. \& Flier, J.S. (2005). Neurogenesis in the hypothalamus of adult mice: potential role in energy balance. Science, Vol.310, No.5748, (October 2005), pp. 67983, ISSN 0036-8075

Konturek, P.C.; Brzozowski, T.; Engel, M.; Burnat, G.; Gaca, P.; Kwiecien, S.; Pajdo, R. \& Konturek, S.J. (2009). Ghrelin ameliorates colonic inflammation. Role of nitric oxide and sensory nerves. Journal of Physiology and Pharmacology, Vol.60, No.2, (June 2009), pp. 41-7, ISSN 0867-5910

Kox, W.J.; Volk, T.; Kox, S.N. \& Volk, H.D. (2000) Immunomodulatory therapies in sepsis. Intensive Care Medicine, Vol.26, No.1, pp. S124-8, ISSN 0342-4642

Lang, C.H.; Frost, R.A.; Nairn, A.C.; MacLean, D.A. \& Vary, T.C. (2002). TNF-alpha impairs heart and skeletal muscle protein synthesis by altering translation initiation. American Journal of Physiology. Endocrinology and Metabolism, Vol.282, No.2, (February 2002), pp. E336-47, ISSN 0193-1849

Laviano, A.; Gleason, J.R.; Meguid, M.M.; Yang, Z.J.; Cangiano, C. \& Rossi Fanelli, F. (2000). Effects of intra-VMN mianserin and IL-1ra on meal number in anorectic tumorbearing rats. Journal of Investigative Medicine, Vol.48, No.1, (January 2000), pp. 40-8, ISSN 1081-5589

Laviano, A.; Inui, A.; Marks, D.L.; Meguid, M.M.; Pichard, C.; Rossi Fanelli, F. \& Seelaender, M. (2008). Neural control of the anorexia-cachexia syndrome. American Journal of Physiology - Endocrinology and Metabolism, Vol.295, No.5, (November 2008), pp. E1000-8, ISSN 0193-1849

Lawrence, C.B. \& Rothwell, N.J. (2001). Anorexic but not pyrogenic actions of interleukin-1 are modulated by central melanocortin-3/4 receptors in the rat. Journal of Neuroendocrinology, Vol.13, No.6, (June 2001), pp. 490-5, ISSN 0953-8194

Leibowitz, S.F.; Weiss, G.F. \& Suh, J.S. (1990). Medial hypothalamic nuclei mediate serotonin's inhibitory effect on feeding behavior. Pharmacology, Biochemistry, and Behavior, Vol.37, No.4, (December 1990), pp. 735-42, ISSN 0091-3057

Lennie, T.A. (1998). Relationship of body energy status to inflammation-induced anorexia and weight loss. Physiology \& Behavior, Vol.64, No.4, (June 1998), pp. 475-81, ISSN 0031-9384

Lennie, T.A.; McCarthy, D.O. \& Keesey, R.E. (1995). Body energy status and the metabolic response to acute inflammation. The American Journal of Physiology, Vol.269, No.5 Pt 2, (November 1995), pp. R1024-31, ISSN 0002-9513

Li, W.; Moylan, J.S.; Chambers, M.A.; Smith, J. \& Reid, M.B. (2009). Interleukin-1 stimulates catabolism in C2C12 myotubes. American Journal of Physiology. Cell Physiology, Vol.297, No.3, (September 2009), pp. C706-14, ISSN 0363-6143 
Li, Y.P. \& Reid, M.B. (2000). NF-kappaB mediates the protein loss induced by TNF-alpha in differentiated skeletal muscle myotubes. American Journal of Physiology. Regulatory, Integrative and Comparative Physiology, Vol.279, No.4, (October 2000), pp. R1165-70, ISSN 0363-6119

Li, Y.P.; Schwartz, R.J.; Waddell, I.D.; Holloway, B.R. \& Reid, M.B. (1998). Skeletal muscle myocytes undergo protein loss and reactive oxygen-mediated NF-kappaB activation in response to tumor necrosis factor alpha. The FASEB Journal, Vol.12, No.10, (July 1998), pp. 871-80, ISSN 0892-6638

Llovera, M.; Garcia-Martinez, C.; Agell, N.; Lopez-Soriano, F.J. \& Argiles, J.M. (1997). TNF can directly induce the expression of ubiquitin-dependent proteolytic system in rat soleus muscles. Biochemical and Biophysical Research Communications, Vol.230, No.2, (January 1997), pp. 238-41, ISSN 0006-291X

Lorton, D.; Lubahn, C.L.; Zautra, A.J. \& Bellinger, D.L. (2008). Proinflammatory cytokines and sickness behavior in rheumatic diseases. Current Pharmaceutical Design, Vol.14, No.13, pp. 1242-60, ISSN 1381-6128

Lugarini, F.; Hrupka, B.J.; Schwartz, G.J.; Plata-Salaman, C.R. \& Langhans, W. (2005). Acute and chronic administration of immunomodulators induces anorexia in Zucker rats. Physiology \& Behavior, Vol.84, No.1, (January 2005), pp. 165-73, ISSN 0031-9384

Luheshi, G.N.; Gardner, J.D.; Rushforth, D.A.; Loudon, A.S. \& Rothwell, N.J. (1999). Leptin actions on food intake and body temperature are mediated by IL-1. Proceedings of the National Academy of Sciences of the United States of America, Vol.96, No.12, (June 1995), pp. 7047-52, ISSN 0027-8424

Marzetti, E.; Carter, C.S.; Wohlgemuth, S.E.; Lees, H.A.; Giovannini, S.; Anderson, B.; Quinn, L.S. \& Leeuwenburgh, C. (2009). Changes in IL-15 expression and death-receptor apoptotic signaling in rat gastrocnemius muscle with aging and life-long calorie restriction. Mechanisms of Ageing and Development, Vol.130, No.4, (April 2009), pp. 272-80, ISSN 0047-6374

Matthys, P. \& Billiau, A. (1997). Cytokines and cachexia. Nutrition, Vol.13, No.9, (September 1997), pp. 763-70, ISSN 0899-9007

McCarthy, H.D.; Dryden, S. \& Williams, G. (1995). Interleukin-1 beta-induced anorexia and pyrexia in rat: relationship to hypothalamic neuropeptide Y. The American Journal of Physiology, Vol.269, No.5 Pt 1, (November 1995), pp. E852-7, ISSN 0002-9513

Memon, R.A.; Grunfeld, C.; Moser, A.H. \& Feingold, K.R. (1993). Tumor necrosis factor mediates the effects of endotoxin on cholesterol and triglyceride metabolism in mice. Endocrinology, Vol.132, No.5, (May 1993), pp. 2246-53, ISSN 0013-7227

Metzger, S.; Begleibter, N.; Barash, V.; Drize, O.; Peretz, T.; Shiloni, E. \& Chajek-Shaul, T. (1997a). Tumor necrosis factor inhibits the transcriptional rate of glucose-6phosphatase in vivo and in vitro. Metabolism: Clinical and Experimental, Vol.46, No.5, (May 1997), pp. 579-83, ISSN 0026-0495

Metzger, S.; Goldschmidt, N.; Barash, V.; Peretz, T.; Drize, O.; Shilyansky, J.; Shiloni, E. \& Chajek-Shaul, T. (1997b). Interleukin-6 secretion in mice is associated with reduced glucose-6-phosphatase and liver glycogen levels. The American Journal of Physiology, Vol.273, No.2 Pt 1, (August 1997), pp. E262-7, ISSN 0002-9513

Metzger, S.; Nusair, S.; Planer, D.; Barash, V.; Pappo, O.; Shilyansky, J. \& Chajek-Shaul, T. (2004). Inhibition of hepatic gluconeogenesis and enhanced glucose uptake 
contribute to the development of hypoglycemia in mice bearing interleukin-1betasecreting tumor. Endocrinology, Vol.145, No.11, (November 2004), pp. 5150-6, ISSN 0013-7227

Morgan, J.E. \& Partridge, T.A. (2003). Muscle satellite cells. The International Journal of Biochemistry E Cell Biology, Vol.35, No.8, (August 2003), pp. 1151-6, ISSN 1357-2725

Morley, J.E.; Thomas, D.R. \& Wilson, M.M. (2006). Cachexia: pathophysiology and clinical relevance. The American Journal of Clinical Nutrition, Vol.83, No.4, (April 2006), pp. 735-43, ISSN 0002-9165

Mrosovsky, N.; Molony, L.A.; Conn, C.A. \& Kluger, M.J. (1989). Anorexic effects of interleukin 1 in the rat. The American journal of physiology, Vol.257, No. $6 \mathrm{Pt} 2$, (December 1989), pp. R1315-21, ISSN 0002-9513

Nadjar, A.; Bluthé, R.M.; May, M.J.; Dantzer, R. \& Parnet, P. (2005). Inactivation of the cerebral NFkappaB pathway inhibits interleukin-1beta-induced sickness behavior and c-Fos expression in various brain nuclei. Neuropsychopharmacology, Vol.30, No.8, (August 2005), pp. 1492-9, ISSN 0893-133X

Ogimoto, K.; Harris, M.K. Jr. \& Wisse, B.E. (2006). MyD88 is a key mediator of anorexia, but not weight loss, induced by lipopolysaccharide and interleukin-1 beta. Endocrinology, Vol.147, No.9, (September 2006), pp. 4445-53, ISSN 0013-7227

Ollmann, M.M.; Wilson, B.D.; Yang, Y.K.; Kerns, J.A.; Chen, Y.; Gantz, I. \& Barsh, G.S. (1997). Antagonism of central melanocortin receptors in vitro and in vivo by agoutirelated protein. Science, Vol.278, No.5335, (October 1997), pp. 135-8, ISSN 0036-8075

Pajak, B.; Orzechowska, S.; Pijet, B.; Pijet, M.; Pogorzelska, A.; Gajkowska, B. \& Orzechowski, A. (2008). Crossroads of cytokine signaling--the chase to stop muscle cachexia. Journal of Physiology and Pharmacology, Vol.59, No.9, (December 2008), pp. 251-64, ISSN 0867-5910

Pedersen, B.K. \& Febbraio, M.A. (2008). Muscle as an endocrine organ: focus on musclederived interleukin-6. Physiological Reviews, Vol.88, No.4, (October 2008) pp. 1379406, ISSN0031-9333

Petrovic-Rackov, L. \& Pejnovic, N. (2006). Clinical significance of IL-18, IL-15, IL-12 and TNF-alpha measurement in rheumatoid arthritis. Clinical Rheumatology, Vol.25, No.4, (July 2006), pp. 448-52, ISSN 0770-3198

Pistilli, E.E. \& Alway, S.E. (2008). Systemic elevation of interleukin-15 in vivo promotes apoptosis in skeletal muscles of young adult and aged rats. Biochemical and Biophysical Research Communications, Vol.373, No.1, (August 2008), pp. 20-4, ISSN 0006-291X

Plata-Salaman, C.R.; Ilyin, S.E. \& Gayle, D. (1998). Brain cytokine mRNAs in anorectic rats bearing prostate adenocarcinoma tumor cells. The American Journal of Physiology, Vol.275, No.2 Pt 2, (August 1998), pp. R566-73, ISSN 0002-9513

Quinn, L.S.; Anderson, B.G.; Drivdahl, R.H.; Alvarez, B. \& Argiles, J.M. (2002). Overexpression of interleukin-15 induces skeletal muscle hypertrophy in vitro: implications for treatment of muscle wasting disorders. Experimental Cell Research, Vol.280, No.1, (October 2002), pp. 55-63, ISSN 0099-9539

Quinn, L.S.; Haugk, K.L. \& Grabstein, K.H. (1995). Interleukin-15: a novel anabolic cytokine for skeletal muscle. Endocrinology, Vol.136, No.8, (August 1995), pp. 3669-72, ISSN 0013-7227

Raetzsch, C.F.; Brooks, N.L.; Alderman, J.M.; Moore, K.S.; Hosick, P.A.; Klebanov, S.; Akira, S.; Bear, J.E.; Baldwin, A.S.; Mackman, N. \& Combs, T.P. (2009). Lipopolysaccharide 
inhibition of glucose production through the Toll-like receptor-4, myeloid differentiation factor 88, and nuclear factor kappa b pathway. Hepatology, Vol.50, No.2, (August 2009), pp. 592-600, ISSN 0270-9139

Rauchhaus, M.; Koloczek, V.; Volk, H.; Kemp, M.; Niebauer, J.; Francis, D.P.; Coats, A.J. \& Anker, S.D. (2000). Inflammatory cytokines and the possible immunological role for lipoproteins in chronic heart failure. International Journal of Cardiology, Vol.76, No.23, (November - December 2000), pp. 125-33, ISSN 0167-5273

Reyes-Vazquez, C.; Prieto-Gomez, B. \& Dafny, N. (1994). Alpha-interferon suppresses food intake and neuronal activity of the lateral hypothalamus. Neuropharmacology, Vol. 33, No.12, (December 1994), pp. 1545-52, ISSN 0028-3908

Rothwell, N.J. \& Luheshi, G. (1994). Pharmacology of interleukin-1 actions in the brain. Advances in Pharmacology, Vol.25, pp. 1-20, ISSN 1687-6334

Rotter, V.; Nagaev, I. \& Smith, U. (2003). Interleukin-6 (IL-6) induces insulin resistance in 3T3-L1 adipocytes and is, like IL-8 and tumor necrosis factor-alpha, overexpressed in human fat cells from insulin-resistant subjects. The Journal of Biological Chemistry, Vol.278, No.46, (November 2003), pp. 45777-84, ISSN 0021-9258

Roubenoff, R.; Roubenoff, R.A.; Cannon, J.G.; Kehayias, J.J.; Zhuang, H.; Dawson-Hughes, B.; Dinarello, C.A. \& Rosenberg, I.H. (1994). Rheumatoid cachexia: cytokine-driven hypermetabolism accompanying reduced body cell mass in chronic inflammation. The Journal of Clinical Investigation, Vol.93, No.6, (June 1994), pp. 2379-86, ISSN 00219738

Sanna, V.; Di Giacomo, A.; La Cava, A.; Lechler, R.I.; Fontana, S.; Zappacosta, S. \& Matarese, G. (2003). Leptin surge precedes onset of autoimmune encephalomyelitis and correlates with development of pathogenic $\mathrm{T}$ cell responses. The Journal of Clinical investigation, Vol.111, No.2, (January 2003), pp. 241-50, ISSN 0021-9738

Scarlett, J.M.; Jobst, E.E.; Enriori, P.J.; Bowe, D.D.; Batra, A.K.; Grant, W.F.; Cowley, M.A. \& Marks, D.L. (2007). Regulation of central melanocortin signaling by interleukin-1 $\beta$. Endocrinology, Vol.148, No.9, (September 2007), pp. 4217-25, ISSN 0013-7227

Scarlett, J.M.; Zhu, X.; Enriori, P.J.; Bowe, D.D.; Batra, A.K.; Levasseur, P.R.; Grant, W.F.; Meguid, M.M.; Cowley, M.A. \& Marks, D.L. (2008). Regulation of agouti-related protein messenger ribonucleic acid transcription and peptide secretion by acute and chronic inflammation. Endocrinology, Vol.149, No.10, (October 2008), pp. 483745, ISSN 0013-7227

Schols, A.M.; Buurman, W.A.; Staal van den Brekel, A.J.; Dentener, M.A. \& Wouters, E.F. (1996). Evidence for a relation between metabolic derangements and increased levels of inflammatory mediators in a subgroup of patients with chronic obstructive pulmonary disease. Thorax, Vol.51, No.8, (August 1996), pp. 819-24, ISSN 0040-6376

Schwartz, G.J. (2002). Neural-immune gut-brain communication in the anorexia of disease. Nutrition, Vol.18, No.6, (June 2002), pp. 528-33, ISSN 0899-9007

Shelton, G.D.; Calcutt, N.A.; Garrett, R.S.; Gu, D.; Sarvetnick, N.; Campana, W.M. \& Powell, H.C. (1999). Necrotizing myopathy induced by overexpression of interferongamma in transgenic mice. Muscle E Nerve, Vol.22, No.2, (February 1999), pp. 15665, ISSN 0148-639X

Singh, B.; Arora, S. \& Khanna, V. (2010) Association of severity of COPD with IgE and interleukin-1 beta. Monaldi Archives for Chest Disease, Vol.73, No.2, (June 2010), pp. 86-7, ISSN 1122-0643 
Sishi, B.J. \& Engelbrecht, A.M. (2011). Tumor necrosis factor alpha (TNF-a) inactivates the PI3-kinase/PKB pathway and induces atrophy and apoptosis in L6 myotubes. Cytokine, Vol.54, No.2, (May 2011), pp. 173-84, ISSN 1043-4666

Smiechowska, J.; Utech, A.; Taffet, G.; Hayes, T.; Marcelli, M. \& Garcia, J.M. (2010). Adipokines in patients with cancer anorexia and cachexia. Journal of Investigative Medicine: The Official Publication of the American Federation for Clinical Research, Vol.58, No.3, (March 2010), pp. 554-9, ISSN 1081-5589

Sonti, G.; Ilyin, S.E. \& Plata-Salaman, C.R. (1996). Anorexia induced by cytokine interactions at pathophysiological concentrations. The American Journal of Physiology, Vol.270, No.6 Pt 2, (June 1996), pp. R1394-1402, ISSN 0002-9513

Sonti, G.; Ilyin, S.E. \& Plata-Salamán, C.R. (1996). Neuropeptide Y blocks and reverses interleukin-1 beta-induced anorexia in rats. Peptides, Vol.17, No.3, pp. 517-20, ISSN 0196-9781

Stienstra, R.; Saudale, F.; Duval, C.; Keshtkar, S.; Groener, J.E.; van Rooijen, N.; Staels, B.; Kersten, S. \& Muller, M. (2010). Kupffer cells promote hepatic steatosis via interleukin-1beta-dependent suppression of peroxisome proliferator-activated receptor alpha activity. Hepatology, Vol.51, No.2, (February 2010), pp. 511-22, ISSN 0270-9139

Stockli, K.A.; Lottspeich, F.; Sendtner, M.; Masiakowski, P.; Carroll, P.; Gotz, R.; Lindholm, D. \& Thoenen, H. (1989). Molecular cloning, expression and regional distribution of rat ciliary neurotrophic factor. Nature, Vol.342, No.6252, (December 1989), pp. 9203, ISSN 0028-0836

Stofkova, A. (2009a). Leptin and adiponectin: from energy and metabolic dysbalance to inflammation and autoimmunity. Endocrine Regulations, Vol.43, No.4, (October 2009), pp. 157-68, ISSN 1210-0668

Stofkova, A.; Haluzik, M.; Zelezna, B.; Kiss, A.; Skurlova, M.; Lacinova, Z. \& Jurcovicova, J. (2009b). Enhanced expressions of mRNA for neuropeptide $Y$ and interleukin 1 beta in hypothalamic arcuate nuclei during adjuvant arthritis-induced anorexia in Lewis rats. Neuroimmunomodulation, Vol.16, No.6, pp. 377-84, ISSN 1021-7401

Stofkova, A.; Zelezna, B.; Romzova, M.; Ulicna, O.; Kiss, A.; Skurlova, M. \& Jurcovicova, J. (2010). Effect of feeding status on adjuvant arthritis severity, cachexia and insulin sensitivity in male Lewis rats. Mediators of Inflammation, Vol. 2010, No. pii: 398026 (September 2010) pp. 1-12, ISSN 0962-9351

Straub, R.H.; Cutolo, M.; Buttgereit, F. \& Pongratz, G. (2010). Energy regulation and neuroendocrine-immune control in chronic inflammatory diseases. Journal of Internal Medicine, Vol.267, No.6, (Jan 2010), pp. 543-60, ISSN 0954-6820

Strle, K.; McCusker, R.H.; Johnson, R.W.; Zunich, S.M.; Dantzer, R. \& Kelley, K.W. (2008). Prototypical anti-inflammatory cytokine IL-10 prevents loss of IGF-I-induced myogenin protein expression caused by IL-1beta. American Journal of Physiology. Endocrinology and Metabolism, Vol.294, No.4, (April 2008), pp. E709-18, ISSN 01931849

Suto, G.; Kiraly, A.; Plourde, V. \& Tache, Y. (1996). Intravenous interleukin-1-beta-induced inhibition of gastric emptying: involvement of central corticotrophin-releasing factor and prostaglandin pathways in rats. Digestion, Vol.57, No.2, pp. 135-40, ISSN 0012-2823

Theil, M.M.; Miyake, S.; Mizuno, M.; Tomi, C.; Croxford, J.L.; Hosoda, H.; Theil, J.; von Hörsten, S.; Yokote, H.; Chiba, A.; Lin, Y.; Oki, S.; Akamizu, T.; Kangawa, K. \& 
Yamamura T. (2009). Suppression of experimental autoimmune encephalomyelitis by ghrelin. The Journal of Immunology, Vol.183, No.4, (August 2009), pp. 2859-66, ISSN 0022-1767

Tijerina, A.J. (2004). The biochemical basis of metabolism in cancer cachexia. Dimensions of Critical Care Nursing, Vol.23, No.6, (December 2004), pp. 237-43, ISSN 0730-4625

Tisdale, M.J. (2007). Is there a common mechanism linking muscle wasting in various disease types? Current Opinion in Supportive and Palliative Care, Vol.1, No.4, (December 2007), pp. 287-92, ISSN 1751-4258

Tisdale, M.J. (2008). Catabolic mediators of cancer cachexia. Current Opinion in Supportive and Palliative Care, Vol.2, No.4, (December 2008), pp. 256-61, ISSN 1751-4258

Tolosa, L.; Morla, M.; Iglesias, A.; Busquets, X.; Llado, J. \& Olmos, G. (2005). IFN-gamma prevents TNF-alpha-induced apoptosis in C2C12 myotubes through downregulation of TNF-R2 and increased NF-kappaB activity. Cellular Signalling, Vol.17, No.11, (November 2005), pp. 1333-42, ISSN 0898-6568

Torre-Amione, G.; Kapadia, S.; Benedict, C.; Oral, H.; Young, J.B. \& Mann, D.L. (1996). Proinflammatory cytokine levels in patients with depressed left ventricular ejection fraction: a report from the Studies of Left Ventricular Dysfunction (SOLVD). Journal of the American College of Cardiology, Vol.27, No.5, (April 1996), pp. 1201-6, ISSN 0735-1097

Turrin, N.P.; Flynn, M.C. \& Plata-Salaman, C.R. (1999). Neuropeptide Y counteracts interferon-alpha-induced anorexia. Neuroimmunomodulation, Vol.6, No.5, (September - October 1999), pp. 361-6, ISSN 1021-7401

Ueki, K.; Kondo, T. \& Kahn, C.R. (2004). Suppressor of cytokine signaling 1 (SOCS-1) and SOCS-3 cause insulin resistance through inhibition of tyrosine phosphorylation of insulin receptor substrate proteins by discrete mechanisms. Cellular and Molecular Biology, Vol.24, No.12, (June 2004), pp. 5434-46, ISSN 0145-5680

Valassi, E.; Scacchi, M. \& Cavagnini, F. (2008). Neuroendocrine control of food intake. Nutrition, metabolism, and cardiovascular diseases, Vol.18, No.2, (February 2008), pp. 158-68, ISSN 0939-4753

Vaziri, N.D. \& Norris, K. (2011). Lipid disorders and their relevance to outcomes in chronic kidney disease. Blood Purification, Vol.31, No.1-3, pp. 189-96, ISSN 0253-5068

von Haehling, S.; Hopkinson, N.S.; Polkey, M.I.; Niethammer, M.; Anker, S.D. \& GenthZotz, S. (2009). Elevated TNFalpha production in whole blood in patients with severe COPD: the potential link to disease severity. Wiener Klinische Wochenschrift, Vol.121, No.9-10, pp. 303-8, ISSN 0043-5325

Waldmann, T.A.; Lugli, E.; Roederer, M.; Perera, L.P.; Smedley, J.V.; Macallister, R.P.; Goldman, C.K.; Bryant, B.R.; Decker, J.M.; Fleisher, T.A.; Lane, H.C.; Sneller, M.C.; Kurlander, R.J.; Kleiner, D.E.; Pletcher, J.M.; Figg, W.D.; Yovandich, J.L. \& Creekmore, S.P. (2011). Safety (toxicity), pharmacokinetics, immunogenicity, and impact on elements of the normal immune system of recombinant human IL-15 in rhesus macaques. Blood, Vol.117, No.18, (May 2011), pp. 4787-95, ISSN 0006-4971

Wang, K.; Yuan, C.P.; Wang, W.; Yang, Z.Q.; Cui, W.; Mu, L.Z.; Yue, Z.P.; Yin, X.L.; Hu, Z.M. \& Liu, J.X. (2010). Expression of interleukin 6 in brain and colon of rats with TNBS-induced colitis. World Journal Gastroenterology, Vol.16, No.18, (May 2010), pp. 2252-9, ISSN1007-9327 
Wang, W.; Lonnroth, C.; Svanberg, E.; Lundholm, K. (2001). Cytokine and cyclooxygenase-2 protein in brain areas of tumor-bearing mice with prostanoid-related anorexia. Cancer Research, Vol.61, No.12, (June 2001), pp. 4707-15, ISSN 1538-7445

Weigert, C.; Hennige, A.M.; Lehmann, R.; Brodbeck, K.; Baumgartner, F.; Schauble, M.; Haring, H.U. \& Schleicher, E.D. (2006). Direct cross-talk of interleukin-6 and insulin signal transduction via insulin receptor substrate-1 in skeletal muscle cells. The Journal of Biological Chemistry, Vol.281, No.11, (March 2006), pp. 7060-7, ISSN 00219258

White, J.P.; Baltgalvis, K.A.; Puppa, M.J.; Sato, S.; Baynes, J.W. \& Carson, J.A. (2010). Muscle oxidative capacity during IL-6-dependent cancer cachexia. American Journal of Physiology. Regulatory, Integrative and Comparative Physiology, Vol.300, No.2, (February 2011), pp. R201-11, ISSN 0363-6119

Wisse, B.E.; Ogimoto, K.; Morton, G.J.; Williams, D.L. \& Schwartz, M.W. (2007a). Central interleukin-1 (IL1) signaling is required for pharmacological, but not physiological, effects of leptin on energy balance. Brain Research, Vol.1144, No., (May 2007), pp. 101-6, ISSN 0006-8993

Wisse, B.E.; Ogimoto, K.; Tang, J.; Harris, M.K. Jr.; Raines, E.W. \& Schwartz, M.W. (2007b). Evidence that lipopolysaccharide-induced anorexia depends upon central, rather than peripheral, inflammatory signals. Endocrinology, Vol.148, No.11, (November 2007), pp. 5230-7, ISSN 0013-7227

Wu, R.; Dong, W.; Zhou, M.; Zhang, F.; Marini, C.P.; Ravikumar, T.S. \& Wang, P. (2007). Ghrelin attenuates sepsis-induced acute lung injury and mortality in rats. American Journal of Respiratory and Critical Care Medicine, Vol.176, No.6, (October 2007), pp. 805-13, ISSN 1073-449X

Xu, B.; Dube, M.G.; Kalra, P.S.; Farmerie, W.G.; Kaibara, A.; Moldawer, L.L.; Martin, D. \& Kalra, S.P. (1998). Anorectic effects of the cytokine, ciliary neurotropic factor, are mediated by hypothalamic neuropeptide Y: comparison with leptin. Endocrinology, Vol.139, No.2, (February 1998), pp. 466-73, ISSN 0013-7227

Yang, Z.J.; Blaha, V.; Meguid, M.M.; Laviano, A.; Oler, A. \& Zadak, Z. (1999). Interleukin1alpha injection into ventromedial hypothalamic nucleus of normal rats depresses food intake and increases release of dopamine and serotonin. Pharmacology, Biochemistry, and Behavior, Vol.62, No.1, (January 1999), pp. 61-5, ISSN 0091-3057

Zamir, O.; Hasselgren, P.O.; O'Brien, W.; Thompson, R.C. \& Fischer, J.E. (1992). Muscle protein breakdown during endotoxemia in rats and after treatment with interleukin-1 receptor antagonist (IL-1ra). Annals of Surgery, Vol.216, No.3, (September 1992), pp. 381-5, ISSN0003-4932

Zamir, O.; Hasselgren, P.O.; von Allmen, D. \& Fischer, J.E. (1993). In vivo administration of interleukin-1 alpha induces muscle proteolysis in normal and adrenalectomized rats. Metabolism: Clinical and Experimental, Vol.42, No.2, (February 1993), pp. 204-8, ISSN 0026-0495

Zamir, O.; O'Brien, W.; Thompson, R.; Bloedow, D.C.; Fischer, J.E. \& Hasselgren, P.O. (1994). Reduced muscle protein breakdown in septic rats following treatment with interleukin-1 receptor antagonist. The International Journal of Biochemistry, Vol.26, No.7, (July 1994), pp. 943-50, ISSN 0020-711X

Zhang, K.; Sha, J. \& Harter, M.L. (2010). Activation of Cdc6 by MyoD is associated with the expansion of quiescent myogenic satellite cells. The Journal of Cell Biology, Vol.188, No.1, (January 2010), pp. 39-48, ISSN0021-9525 
Zhang, L.; Du, J.; Hu, Z.; Han, G.; Delafontaine, P.; Garcia, G. \& Mitch, W.E. (2009). IL-6 and serum amyloid A synergy mediates angiotensin II-induced muscle wasting. Journal of the American Society of Nephrology, Vol.20, No.3, (March 2009), pp. 604-12, ISSN1046-6673

Zhang, L.; Wang, X.H.; Wang, H.; Du, J. \& Mitch, W.E. (2010). Satellite cell dysfunction and impaired IGF-1 signaling cause CKD-induced muscle atrophy. Journal of the American Society of Nephrology, Vol.21, No.3, (March 2010), pp. 419-27, ISSN10466673

Zhang, Y.; Pilon, G.; Marette, A. \& Baracos, V.E. (2000). Cytokines and endotoxin induce cytokine receptors in skeletal muscle. American Journal of Physiology. Endocrinology and Metabolism, Vol.277, No.1, (July 2000), pp. E196-205, ISSN 0193-1849 


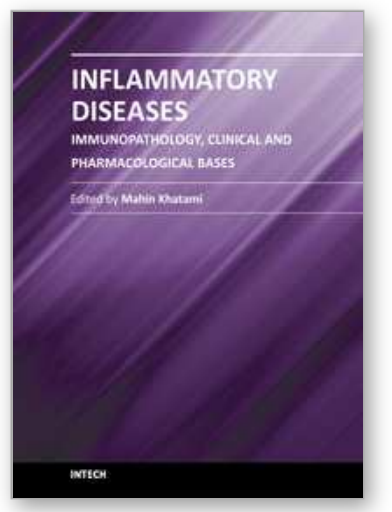

\author{
Inflammatory Diseases - Immunopathology, Clinical and \\ Pharmacological Bases \\ Edited by Dr Mahin Khatami
}

ISBN 978-953-307-911-0

Hard cover, 396 pages

Publisher InTech

Published online 10, February, 2012

Published in print edition February, 2012

This book is a collection of comprehensive reviews contributed by experts in the diverse fields of acute and chronic inflammatory diseases, with emphasis on current pharmacological and diagnostic options. Interested professionals are also encouraged to review the contributions made by experts in a second related book entitled "Inflammation, Chronic Diseases and Cancer"; it deals with immunobiology, clinical reviews, and perspectives of the mechanisms of immune inflammatory responses that are involved in alterations of immune dynamics during the genesis, progression and manifestation of a number of inflammatory diseases and cancers, as well as perspectives for diagnosis, and treatment or prevention of these disabling and potentially preventable diseases, particularly for the growing population of older adults around the globe.

\title{
How to reference
}

In order to correctly reference this scholarly work, feel free to copy and paste the following:

Andrea Stofkova (2012). Cachexia - The Interplay Between the Immune System, Brain Control and Metabolism, Inflammatory Diseases - Immunopathology, Clinical and Pharmacological Bases, Dr Mahin Khatami (Ed.), ISBN: 978-953-307-911-0, InTech, Available from:

http://www.intechopen.com/books/inflammatory-diseases-immunopathology-clinical-and-pharmacologicalbases/cachexia-the-interplay-between-the-immune-system-brain-control-and-metabolism

\section{INTECH}

open science | open minds

\author{
InTech Europe \\ University Campus STeP Ri \\ Slavka Krautzeka 83/A \\ 51000 Rijeka, Croatia \\ Phone: +385 (51) 770447 \\ Fax: +385 (51) 686166 \\ www.intechopen.com
}

\author{
InTech China \\ Unit 405, Office Block, Hotel Equatorial Shanghai \\ No.65, Yan An Road (West), Shanghai, 200040, China \\ 中国上海市延安西路65号上海国际贵都大饭店办公楼 405 单元 \\ Phone: +86-21-62489820 \\ Fax: +86-21-62489821
}


(C) 2012 The Author(s). Licensee IntechOpen. This is an open access article distributed under the terms of the Creative Commons Attribution 3.0 License, which permits unrestricted use, distribution, and reproduction in any medium, provided the original work is properly cited. 